Maurer School of Law: Indiana University

Digital Repository @ Maurer Law

\title{
Making the World in Atlanta's Image: The Student Nonviolent Coordinating Committee, Morris Abram, and the Legislative History of the United Nations Race Convention
}

H. Timothy Lovelace

Indiana University Maurer School of Law, lovelace@indiana.edu

Follow this and additional works at: https://www.repository.law.indiana.edu/facpub

Part of the Civil Rights and Discrimination Commons, Human Rights Law Commons, and the United States History Commons

\section{Recommended Citation}

Lovelace, H. Timothy, "Making the World in Atlanta's Image: The Student Nonviolent Coordinating Committee, Morris Abram, and the Legislative History of the United Nations Race Convention" (2014).

Articles by Maurer Faculty. 2111.

https://www.repository.law.indiana.edu/facpub/2111

This Article is brought to you for free and open access by the Faculty Scholarship at Digital Repository @ Maurer Law. It has been accepted for inclusion in Articles by Maurer Faculty by an authorized administrator of Digital Repository@Maurer Law. For more information, please contactrvaughan@indiana.edu. 


\section{Making the World in Atlanta's Image: The Student Nonviolent Coordinating Committee, Morris Abram, and the Legislative History of the United Nations Race Convention}

\section{H. TIMOTHY LOVELACE JR.}

Atlanta's human rights community was buzzing, because the United Nations (U.N.) was coming to town. On Sunday, January 19, 1964, the front page of the Atlanta Daily World, the city's oldest black newspaper and the South's only black daily, announced, "United Nations Rights Panel to Visit Atlanta."

H. Timothy Lovelace, Jr. (lovelace@indiana.edu) is an associate professor of law at the Indiana University Maurer School of Law. He dedicates this article to Julian Bond and Pam Horowitz. He received generous and insightful comments from Carol Anderson, Mario Barnes, Julian Bond, Al Brophy, Dorothy Brown, Kevin Brown, Tomiko Brown-Nagin, Guy Charles, Emilye Crosby, Ted Delaney, Ray Diamond, Mary Dudziak, Kim Forde-Mazrui, Luis Fuentes-Rowher, Wendy Greene, Lisa Griffin, Valerie Grim, Mike Grossberg, Risa Goluboff, Paul Haagen, Paul Halliday, Claudrena Harold, Larry Helfer, Deena Hurwitz, Gordon Hylton, Michael Klarman, Adriane Lentz-Smith, Charles McCurdy, Christian McMillen, Deborah McDowell, Ajay Mehrotra, Melissa Murray, Brenda Gayle Plummer, Russell Robinson, Chris Roberts, Bertrall Ross, Marlon Ross, James Sparrow, and Nikhil Singh. Drafts of this article were presented to the Association for the Study of African American Life and History Annual Convention, Carter G. Woodson Institute for African-American and African Studies, University of Virginia Corcoran Department of History, the MidAtlantic People of Color Legal Scholarship Conference, the Policy History Conference, and the Duke Law School Emerging Scholars Program. The author also received helpful feedback on the project during workshops at Brooklyn, Cumberland, Chicago, Colorado, Duke, Emory, Indiana Maurer, Indiana McKinney, Kentucky, Louisiana State University, University of California-Irvine, 
The U.N. Sub-Commission on the Prevention of Discrimination and Protection of Minorities (Sub-Commission), the Daily World explained, was a fourteen nation "body that surveys the worldwide problems of discrimination." The Sub-Commission had been invited to Atlanta by Morris Abram, a former Atlanta attorney and the lone United States member of the Sub-Commission, to study first-hand the city's well-publicized, efforts to improve in race relations. Sunday morning's Daily World also noted that the U.N. delegation "composed of experts, mostly lawyers and jurists" was in the midst of drafting a global treaty designed to end racial discrimination, and the local paper highlighted Abram's role as the primary drafter of the race accord. "Mr. Abram, as the U.S. expert on the subcommission has proposed a sweeping eight-point treaty," the article reported. According to the Daily World, the pending race treaty - the treaty that would ultimately become the International Convention on the Elimination of All Forms of Racial Discrimination (ICERD or Convention)--would address "segregation, hate groups and discrimination in public accommodations."1

By Sunday afternoon, the Student Nonviolent Coordinating Committee (SNCC) had organized "a rally of approximately 200 on the Atlanta University campus" to discuss a bold, new phase in the Southern freedom movement. In January 1964, SNCC, the "shock troops" of the movement, had been at the forefront of a renewed campaign against Jim Crow in the Georgia capital. But the news flowing from the Daily World's Sweet Auburn Avenue presses on Sunday January 19 further galvanized the student activists. Speakers at the Atlanta University Campus rally "urged students of the city's Negro colleges to prepare for more demonstrations" in the coming days, and SNCC revealed its plans to petition the Sub-Commission from the streets of Atlanta. In particular, John Lewis, SNCC Chairman and Baptist preacher, delivered a stirring sermon to the congregation of young dissidents. Lewis declared to rally-goers that SNCC would disregard conventional channels of diplomacy and launch protests that the United States State Department would deem "embarrassing to the nation." Lewis, connecting the local struggle for racial equality

1. "United Nations Panel to Visit Atlanta," Atlanta Daily World, January 19, 1964, 1. See also International Convention on the Elimination of All Forms of Racial Discrimination, January 4, 1969, 660 U.N.T.S. 195 (hereafter ICERD).

University of California-Berkeley, and Washington and Lee. G. Woodson Institute for African-American and African Studies, the Virginia Foundation for the Humanities, and the University of Virginia, Corcoran Department of History. Archivists at the John F. Kennedy Library, Library of Congress, National Archives, Emory University, and Woodruff Library of the Atlanta University Center provided invaluable research assistance. 
to the U.N.'s global campaign to eliminate racial discrimination, maintained that these SNCC-led, "demonstrations would be for the benefit of a visiting U.N. group."2

This article examines the dynamic relationship between the Atlanta student movement and the U.N.'s development of international human rights law. Such an endeavor benefits from three critical historiographical shifts within the civil rights canon over the last two decades. First, this article relies on a well-established body of scholarship that underscores that the United States civil rights movement was primarily a mass movement in which local people attempted to transform their lives for themselves. These scholars have demonstrated that the participants in local struggles played a vital role in creating conditions for many of the social, political, and legal changes the nation experienced during the civil rights movement. ${ }^{3}$ Second, my work is part of the changing face of diplomatic history. ${ }^{4}$ In particular, this article engages a cadre of movement historians, who have skillfully chronicled the creative strategies that many non-state actors employed to shame the United States on the international stage

2. "73 Demonstrators Released on Bond," Atlanta Constitution, January 20, 1964, 3.

3. See, for example, Charles Payne, I've Got the Light of Freedom: Organizing Tradition and the Mississippi Freedom Struggle (Berkeley: University of California Press, 1997); and John Dittmer, Local People: The Struggle for Civil Rights in Mississippi (Urbana: University of Illinois Press, 1995). See also Tomiko Brown-Nagin, Courage to Dissent: Atlanta and the Long History of the Civil Rights Movement (New York: Oxford University Press, 2011).

4. See Brenda Gayle Plummer, "The Changing Face of Diplomatic History: A Literature Review," The History Teacher 38 (2005): 385. See also Henry Richardson, III, The Origins of African-American Interests in International Law (Durham: Carolina Academic Press, 2008); Carol Anderson, Eyes Off the Prize: The United Nations and the African American Struggle for Human Rights, 1944-1955 (Cambridge: Cambridge University Press, 2003); Thomas Borstelmann, The Cold War and the Color Line: American Race Relations in the Global Arena (Cambridge: Harvard University Press, 2003); Brenda Gayle Plummer, Window on Freedom: Race, Civil Rights, and Foreign Affairs, 19451988 (Chapel Hill: University of North Carolina Press, 2003); James Meriweather, Proudly We Can Be Africans: Black Americans and Africa, 1935-1961 (Chapel Hill: University of North Carolina Press, 2002); Mary Dudziak, Cold War Civil Rights: Race and the Image of American Democracy (Princeton: Princeton University Press, 2000); Penny Von Eschen, Race Against Empire: Black Americans and Anticolonialism, 19371957 (Ithaca: Cornell University Press, 1997); Brenda Gayle Plummer, Rising Wind: Black Americans and U.S. Foreign Affairs, 1935-1960 (Chapel Hill: University of North Carolina Press, 1996); and Gerald Horne, Black and Red: W.E.B. Du Bois and the Afro-American Response to the Cold War, 1944-1963 (Albany: State University of New York Press, 1986). For other, innovative historical studies exploring United States contributions to international human rights law, see, for example, Elizabeth Borgwardt, $\mathrm{ANew}$ Deal for the World: America's Vision for Human Rights (Cambridge: Harvard University Press, 2005); and Mary Ann Glendon, A World Made New: Eleanor Roosevelt and the Universal Declaration of Human Rights (New York: Random House, 2001). 
for its domestic human rights abuses. Finally, this article builds on the contributions of a new generation of scholars who explore SNCC's internationalist work in the years preceding the organization's move toward black power. These movement historians emphasize that SNCC was never solely preoccupied with domestic issues. Rather, the organization had a more expansive, internationalist vision, as SNCC activists lobbied foreign officials, appealed to international media outlets, and developed transnational linkages with anticolonial, social movements. ${ }^{5}$ In this article, I fuse these three historiographical interventions together and add a new dimension to the extant literature: an analysis of SNCC's interest in international human rights law. Accordingly, this article explores how SNCC's uncompromising activism in Jim Crow Atlanta helped to inform the development of the ICERD.

Here I make two claims. The first is that the Sub-Commission closely studied the civil rights movement in the U.S. South as it drafted the most explosive provision in the Convention. This claim results from this article's departure from the dominant methodological approach to writing ICRED's history. Natan Lerner's study of ICERD, The U.N. Convention on the Elimination of All Forms of Racial Discrimination, supplies much of the legislative history of the Convention and is a foundational text in the Convention's historiography. Lerner's influential book is an internalist account of ICERD's formation; his narrative carefully tracks the Convention debates within various U.N. organs. ${ }^{6}$ This article, however, utilizes a different historical method to capture the Sub-Commission's ICERD deliberations. It examines this set of deliberations from a sociolegal perspective. This article demonstrates that the Sub-Commission's fierce debates over the provision that became Article 4 in the Convention-a provision that criminalized hate speech and hate organizations-were informed by the Sub-Commission's January 1964 study of race relations in Atlanta, Georgia. ${ }^{7}$ Similarly, this article's methodological framework connects the Sub-Commission's study of Atlanta to an important body of scholarly

5. Fanon Che Wilkins, "The Making of Black Internationalists: SNCC and Africa before the Launching of Black Power, 1960-1965," Journal of African American History 92 (2007): 468; and Winston Grady-Willis, Challenging U.S. Apartheid: Atlanta and Black Struggles for Human Rights, 1960-1977 (Durham: Duke University Press, 2006).

6. Natan Lerner, The U.N. Convention on the Elimination of All Forms of Racial Discrimination (Alphen aan den Rijn: Sijthoff and Noordhoff International Publishers, 1980).

7. See ICRED, art. 4. Article 4, among other things, states that parties to the Convention shall criminalize "all dissemination of ideas based on racial superiority or hatred" and "shall declare illegal and prohibit organizations, and also organized and all other propaganda activities, which promote and incite racial discrimination, and shall recognize participation in such organizations or activities as on offence punishable by law." 
articles that discuss Article 4's origins. ${ }^{8}$ A sociolegal approach to Article 4's drafting history creates the analytic space to consider how the SubCommission's interest in the U.S. civil rights movement entangled black Atlantans into the Convention's most polemical debate.

But the Sub-Commission was not simply interested in local activism in Atlanta; my second claim is that local civil rights activists also became riveted by the Sub-Commission's deliberations. Members of SNCC were dumbfounded that U.N. officials would rely on an examination of Atlanta's race relations to draft an international treaty on ending racial discrimination. The organization subsequently leveraged the SubCommission's visit to Atlanta to shame local and federal officials, enhance its prestige, and spread its radical democratic vision globally. This article, accordingly, seeks to contribute to the wealth of outstanding scholarship on the civil rights movement in Atlanta by underscoring the historiographical significance of the Atlanta affiliate's petition to the U.N. ${ }^{9}$ Few civil rights histories even mention SNCC's January 1964 appeal for human

8. See, for example, Stephanie Farrior, "Molding the Matrix: The Historical and Theoretical Foundations of International Law Concerning Hate Speech," 14 Berkeley Journal of International Law (1996): 1; Elizabeth Defeis, "Freedom of Speech and International Norms: A Response to Hate Speech," 29 Stanford Journal of International Law (1992): 57; Mari Matsuda, "Public Response to Racist Speech: Considering the Victim's Story," 87 Michigan Law Review (1989): 2320; Theodor Meron, "The Meaning and Reach of the International Convention on the Elimination of All Forms of Racial Discrimination," 79 American Journal of International Law (1985): 283; Thomas Jones, "Article 4 of the International Convention on the Elimination of All Forms of Racial Discrimination and the First Amendment," 23 Howard Law Journal (1980): 429; Egon Schwelb, "The International Convention on the Elimination of All Forms of Racial Discrimination," 15 International and Comparative Law Quarterly (1996): 996.

9. See, for example, Brown-Nagin, Courage to Dissent; Grady-Willis, Challenging U.S. Apartheid; Alton Hornsby, Jr., Black Power in Dixie: A Political History of African. Americans in Atlanta (Gainesville: University Press of Florida, 2009); Wesley C. Hogan, Many Minds, One Heart: SNCC's Dream for a New America (Chapel Hill: University of North Carolina Press, 2007); Matthew Lassiter, The Silent Majority: Suburban Politics in the Sunbelt South (Princeton: Princeton University Press, 2006); Kevin Kruse, White Flight: Atlanta and the Making of Modern Conservatism (Princeton: Princeton University Press, 2005); Kathryn Nasstrom, "Down to Now: Memory, Narrative, and Women's Leadership in the Civil Rights Movement in Atlanta, Georgia," 11 Gender and History (2002): 113; Herman Mason, Politics, Civil Rights, and Law in Black Atlanta, 1870-1970 (Charleston: Arcadia Publishing, 2000); Ronald Bayor, Race and the Shaping of Twentieth Century Atlanta (Chapel Hill: University of North Carolina, 1996); David Andrew Harmon, Beneath the Image of the Civil Rights Movement and Race Relations, Atlanta, Georgia, 1946-1981 (New York: Garland, 1996); Adam Fairclough, To Redeem the Soul of America (Athens: University of Georgia, 1987); Clayborne Carson, In Struggle: SNCC and the Black Awakening of the 1960s (Cambridge: Harvard University Press, 1981). 
rights. ${ }^{10}$ This article devotes sustained attention to SNCC's interest in international human rights law and uses legal history to complement the earlier, social and political histories of the Atlanta demonstrations. In turn, this article unveils the voices of local actors in the Sub-Commission's deliberations, highlighting how SNCC's affiliate in Atlanta became intimately involved in ICERD's drafting through the organization's interest in the Sub-Commission's visit and unwavering commitment to extraparliamentary social motion.

Part I of this article explores the struggle for racial equality in Atlanta during the early and mid-1960s. Part II examines Article 4's legislative history by returning to the Sub-Commission's tense debates over criminalizing hate speech and hate organizations. Here, the article explains why Article 4 became the most controversial issue during the ICERD debates and how Abram attempted to use the Sub-Commission's trip to Atlanta to amend this provision in the draft Convention. Part III revisits the U.N. group's Southern sojourn, detailing the rich exchanges between the globally minded student activists and the members of the Sub-Commission. Part IV offers concluding remarks, arguing that the formal drafting process of ICERD, like much of the human rights corpus, exposes significant problems and undemocratic aspects of international human rights lawmaking. The fiftieth anniversary of the Atlanta protests is an opportune time to chart a new direction in human and civil rights studies. Toward this end, this article seeks to provide fresh understandings of ICERD and the classical phase of the civil rights movement by considering the role of the Jim Crow South-a geographical region often overlooked when studying the genealogy of the Convention-in the making of global governance.

\section{"Atlanta Needs U.N. Help"}

As James Forman-Executive Secretary of SNCC, student of the organizing tradition, and bold internationalist uniformed in bib overalls to signal his solidarity with working class Southerners-noted in his autobiography, The Making of Black Revolutionaries, "in the fall of 1963, [SNCC] was

10. See Wilkins, The Making of Black Internationalists, 490; Kruse, White Flight, 216; Harmon, Beneath the Image, 185. See also Grady-Willis, Challenging U.S. Apartheid, 205-208. Grady-Willis provides the most critical and thought-provoking analysis of the events surrounding the January 1964 U.N. protests of any historian to date. This article benefits greatly from his scholarship on the movement in Atlanta. 
approaching a new era in the struggle." 11 Though SNCC was only 3 years old, the organization had offered a profound challenge to the elders of the movement during the March on Washington for Jobs and Freedom. In particular, SNCC Chairman John Lewis questioned the unholy alliance between Cold War liberals and the civil rights establishment. He, in his trademark prophetic passion, proclaimed to more than 200,000 on that sweltering August day, "We are now involved in a serious revolution. This nation is still a place of cheap political leaders who build their career on immoral compromises and ally themselves with open forms of political, economic and social exploitation." Lewis continued, "What political leader can stand up and say, 'My party is the party of principles?' The party of Kennedy is also the party of Eastland. The party of Javits is also the party of Goldwater. Where is our party?"12

Moreover, SNCC workers were becoming increasingly critical of the emphasis some in the movement placed on nonviolent resistance. In his 6 month report given in December 1963, Lewis acknowledged that the longstanding theopolitical dispute between SNCC activists on "nonviolence as a technique" as opposed to "nonviolence as a philosophy of life" had reached new proportions. ${ }^{13}$ Nothing made this clearer than many activists' emotional rejoinder to the Sixteenth Street Baptist Church bombing. A time-delayed, dynamite blast rocked the Birmingham civil rights sanctuary, killing four young girls only minutes after that September morning's Sunday school lesson. Forman wrote that this unspeakable attack on innocent children made a "mockery" of the nonviolence preached during the March on Washington. Although SNCC, a group that Martin Luther King, Jr. hoped would become the student wing of the Southern Christian Leadership Conference (SCLC), had been founded on Gandhian principles of nonviolence, Forman observed that after the Sixteenth Street church bombing, "the urge toward retaliatory violence was growing stronger and stronger" among the student activists. ${ }^{14}$

SNCC organizers were also beginning to reframe their demands for racial equality in the fall of 1963 . During Thanksgiving weekend of that year, SNCC's Washington, DC affiliate hosted a national conference

11. James Forman, The Making of Black Revolutionaries (Seattle: University of Washington Press, 1972), 338.

12. Ibid., 336.

13. "John Lewis, Six Month Report," December 27, 1963, Student Nonviolent Coordinating Committee Papers (microfilm), reel 2, frame 40 (hereafter SNCC Papers). See also Howard Zinn, SNCC: The New Abolitionists (Cambridge: South End Press, 1964), 146. "The major difference between us and those who had joined the organization earlier was that we were never committed to nonviolence as anything more than a tactic."

14. Forman, The Making of Black Revolutionaries, 338. 
entitled "One Man, One Vote: Jobs and Food." The conference organizers aimed to compel government leaders "to propose laws which take some money from the wealthy and give it to the poor" and to "challeng[e] private enterprise ... to make jobs available, because every individual has an inherent right to food, clothing, and shelter."15 The theme "One Man, One Vote," a concept popularized by the African National Congress, had become popular in the Southern wing of the freedom movement during 1963, largely because leading SNCC activists, such as Lewis and Forman, had recast their domestic struggle for voting rights in more "revolutionary," anticolonial terms. These developments signaled how by late 1963, SNCC activists were making more explicit connections between the United States civil rights movement and liberation movements abroad, and deepening their criticisms of the political economy by "attack[ing] problems... [blacks] as a people face in [their] daily lives: jobs, housing, education, welfare and medical care."16

As Forman acknowledged, however, in many places throughout the South, civil rights activists were still struggling to desegregate public accommodations in 1963..$^{17}$ Although the federal civil rights bill proposed by President Kennedy gained additional support after the March on Washington, Southern cities, such as Atlanta, Georgia, witnessed violent street clashes over the future of American constitutional law: the meaning of equal protection, the scope of private property rights, and the potential uses of the commerce power. ${ }^{18}$ SNCC had toiled at the intersection of law reform and social change, and in the fall of 1963, its contingent in Atlanta was entering a new phase of this racial saga.

15. "One Man, One Vote: Jobs and Food Conference," November 29-30, 1963, SNCC Papers, reel 55, frame, 14; "Over 300 Attend SNCC Conference," The Student Voice, December 9, 1963, 2.

16. During the March on Washington, Lewis proclaimed, "'One man, one vote,' is the African cry. It is ours, too. It must be ours. Let us tell the Congress: One man, one vote." Forman, The Making of Black Revolutionaries, 337-38.

17. In upper South cities such as Danville, Virginia, the blue-collar town on the North Carolina border, desegregation-minded, SNCC workers braved mounted machine guns, high-pressured fire hoses, riot tanks, and indictments for "incit[ing] the colored population to acts of violence or war against the white population." See "Brutality Scored by SNCC Workers," The Student Voice, August 1963, 2. imilarly, in Deep South areas such as Southwest Georgia, SNCC workers attempting to desegregate movie theatres and cafes were bludgeoned by "police officers ... armed with guns, two-foot clubs, electric cattle prodders, and black jacks." See "Police Smash Demonstrators," The Student Voice, October 1963, 2.

18. Forman, The Making of Black Revolutionaries, 360-61. SNCC's confrontation with these legal issues during the Atlanta sit-ins of the early and mid-1960s became a critical piece of the legislative history of the Civil Rights Act of 1964. See, generally, Brown-Nagin, Courage to Dissent. 
During the civil rights movement, Atlanta, considered the "capital" of the United States South, was hailed as "the city too busy to hate." 19 Atlanta was home to the nation's most extensive collection of historically black colleges, and the city, brimming with an impressive array of blackowned businesses and luxury homes, boasted the country's largest black middle class. Local officials routinely reminded Atlanta's impatient student activists and "outside" onlookers that "Atlanta was no Birmingham," because as Atlanta's moniker suggested, its city fathers claimed to be far more interested in economic development than in simple racial domination. Atlanta's mayor, Ivan Allen, Jr., was the only Southern mayor to testify before Congress in favor of the proposed civil rights bill, and he often credited the longstanding racial brokerage system-an informal arrangement through which select members of the Atlanta's black aristocracy privately negotiated the terms of desegregation with their counterparts in the local, white business community to assuage racial tensions-for the city's racial reputation. ${ }^{20}$ However, in 1963, segregationists in downtown Atlanta had censured him for airing the city's problems before federal officials, and rejected his pleas to desegregate local public accommodations. ${ }^{21}$ Allen later reflected on that moment in the movement: "Atlanta had made strides during the first three years of the sixties, but the battle lines had been drawn quite clearly at the restaurants and the hotel. Everything I had tried in those areas had failed." 22

With a federal civil rights bill looming and Atlanta still a Jim Crow city, the local battle over desegregation intensified in the fall of 1963. Most notably, SNCC and the Committee on Appeal for Human Rights (COAHR), an Atlanta University Center based organization, developed new plans for a wave of protests to break the grip of downtown proprietors. Furthermore, as the student activists strategized for an all-out assault on Jim Crow, a loose coalition of Atlanta area ministers, operating under the umbrella of SCLC's Operation Breadbasket, were negotiating with downtown proprietors regarding segregated business practices. ${ }^{23}$ This

19. William B. Hartsfield, Mayor of Atlanta from 1936 to 1961, coined the city's moniker. See Ronald Bayor, Race and the Shaping of Twentieth Century Atlanta (Chapel Hill: University of North Carolina Press, 1996), 31 .

20. Ivan Allen, Jr., Mayor: Notes on the Sixties (New York: Simon and Schuster, 1971), 90-93, 103. See also Grady-Willis, Challenging U.S. Apartheid, 33; and Harmon, Beneath the Image of the Civil Rights Movement, 152-54.

21. See, generally, Constance Curry Papers, Emory University, Manuscript, Archives, and Rare Book Library, (MARBL), Series 3, Box 9, Folder 7 (hereafter Curry Papers).

22. Allen, Mayor, 103.

23. "Atlanta: Protests and Progress," March 27, 1964, Eliza Paschall Papers, Emory University, MARBL, Series 1, Box 6, Folder 1 (hereafter Paschall Papers). 
local activism culminated on October 19, 1963, when nine civil rights groups and "more than two hundred outstanding leaders of the Atlanta Community" formed an umbrella organization, the Atlanta Summit Leadership Conference (SLC). The SLC devised a comprehensive "battle plan" to attack discrimination in eight key areas: public accommodations, employment, voter registration and education, public school desegregation, health, housing, law enforcement, and political issues. ${ }^{24}$ The Atlanta Daily World, the city's prominent and conservative black newspaper, remarked that the SLC exemplified an "unusually high degree of unity," as the ideologically diverse coalition agreed to make Atlanta an "open city" to all races. ${ }^{25}$

However, over the next several months, the sluggish pace of desegregation frustrated even many of the relatively conservative leaders in the SLC. In the city's tradition of brokerage politics, the SLC's steering committee, co-chaired by 78-year-old, A.T. ("Colonel") Walden, Atlanta's most prominent black attorney and long-time political leader, and Clarence D. Coleman, regional director of the National Urban League, met with various white political, economic, and civic leaders, aiming to encourage negotiations under intense pressure to desegregate. From October to December 1963, the steering committee, now in charge of executing the SLC's "battle plan" to end Jim Crow in Atlanta, participated in a series of meetings with the Chamber of Commerce, the Atlanta School Board, the Atlanta Housing Authority, the Fulton-DeKalb Hospital Authority, the Board of Family Services, and various hotel and restaurant owners. ${ }^{26}$

24. In addition to SNCC and COAHR, the other organizations sponsoring the SLC were the Atlanta Committee for Cooperative Action, the Atlanta Branch of the National Association for the Advancement of Colored People (NAACP), the Atlanta affiliate of the SCLC, the All-Citizens Registration Committee, the Atlanta Negro Voters League, Operation Breadbasket, and the Gandhi Youth Society. More than 200 people attended the meeting. Ibid. See above, note 25.

25. "Saturday's Leadership Conference," Atlanta Daily World, October 22, 1963, 4. See also Grady-Willis, Challenging U.S. Apartheid, 42; and "Action for Democracy," November 1, 1963, Paschall Papers, Series 4, Box 15, Folder 3.

26. "Action for Democracy," November 1, 1963, Paschall Papers, Series 4, Box 15, Folder 3. The SLC clearly understood how Atlanta's racial image was used to counter the negative national and international images of Southern race relations, and the umbrella organization attempted to prick local elites' consciences by using Cold War, civil rights logic. In the SLC's first public document, the group proclaimed, "Presently, Atlanta enjoys the enviable opportunity of being in a position to help resuscitate America's soul and to help revitalize the hopes and aspirations of free people everywhere." Ibid. The formation of the SLC was also significant, because the scope of the group's "battle plan" challenged the widely held misconception that the civil rights movement of the early 1960s was unconcerned with economic justice. For a fuller account of the progressive reforms proposed by the SLC, see "Atlanta Summit Leadership Conference Workshop Report," October 19, 1963, Paschall 
Many of these "moderate" bodies adopted empty resolutions championing the SLC's fundamental goals, but no progress was made. Amid the lingering racial stalemate, and despite an early winter freeze, the SLC mobilized 3,000 Atlantans for a "Pilgrimage for Democracy," a demonstration styled after the March on Washington. ${ }^{27}$. The December rally featured a rare local appearance by the "moral leader of the nation" and Auburn Avenue's own, Dr. Martin Luther King, Jr. Pilgrimage organizers, citing the failed biracial negotiations, challenged the city's leadership and downtown businesses to make real "Atlanta's race relations image, often proudly used to bolster America's image abroad." 28

Groups of white proprietors, in response to the SLC, took out full-page advertisements in the Atlanta Constitution emphasizing the "constitutional" nature of segregation. One advertisement reasoned, "This matter has transcended the consideration of civil rights alone. It now involves the basic right of an individual, any individual of whatever race, creed or color, to engage in business, to purvey any commodity or service which is lawful, to cater to a clientele of its own choosing and, once selected, to honor his obligation to provide the goods and/or services which first prompted the customer's allegiance to the establishment." 29

Papers, Series 4, Box 15, Folder 3; and "Atlanta City-Wide Leadership Conference," n.d., James Forman Papers, Library of Congress, Container 33, Folder Atlanta, 1963-1964 (hereafter Forman Papers).

27. "Leadership Conference Sets for 'Pilgrimage for Democracy," Atlanta Daily World, December 8. 1963, 1; "More Committeemen Coordinate Plans for Sunday Park Assembly," Atlanta Daily World, December 12, 1963, 1; "Sunday Assembly Speakers Named," Atlanta Daily World, December 14, 1963, 1; "Leadership Conference Assembly at Hurt Park Today," Atlanta Daily World, December 15, 1963, 1; "3000 March in Atlanta," The Student Voice, December 16, 1963, 1; and Harmon Perry, "Hurt Park Assembly Draws Many Despite Bitter Cold," Atlanta Daily World, December 17, 1963, 1.

28. "Atlanta Summit Leadership Conference-For Immediate Release," December 10, 1963, Paschall Papers, Series 4, Box 15, Folder 3. The march organizers noted, "This marked the first time many Atlanta Negro adults had participated in any kind of demonstration and the first time that Dr. Martin Luther King, Jr., had spoken in Atlanta at the invitation of all civil rights organizations, although he is a native of Atlanta and co-pastor with his father of a local Baptist Church, and the national office of the Southern Christian Leadership Conference is in Atlanta." Ibid. This appearance was rare, because King attempted to minimize his conflict with Atlanta's moderate racial leadership through an unwritten pledge not to launch demonstrations in his hometown. See Taylor Branch, Pillar of Fire: America in the King Years, 1963-1965 (New York: Simon \& Schuster, 1998), 192.

29. "Paul Good interviewing segregationist Lester Maddox," n.d., Paul Good Papers, Emory University, MARBL, Georgia CDl' (hereafter Good Papers); "Statement by Atlanta Restaurant Association," Atlanta Constitution, January 27, 1964, 20; and M. Charles Baskt, "Atlanta: A Study in Strife," Brown Daily Herald, February 3, 1964, 1. 
The SLC's failure to fully desegregate Atlanta re-ignited the intergenerational debate within black Atlanta about respectable and effective civil rights advocacy. In an internal memorandum dated December 16, 1963, SNCC field secretary, Debbie Amis, noted that "the students have followed the leadership of the Summit Conference ... [yet] this has kept them from taking any initiative or thinking creatively." Amis maintained that "through all the negotiating with the city fathers and financial tycoons, very few of the requests were met with positive action." Citing the generational gap between the "militant activists groups ...ready to "hit the streets" and the "negotiators," Amis concluded that "there can be a student movement independent in program and thinking -in other words, more detached from the conservative adult thought." 30

Accordingly, by late December 1963, the Atlanta student activists commenced protests independent of the SLC, and these demonstrations forged new political strategies and alliances within the global freedom struggle. On December 21, Kenyan Minister of Home Affairs Oginga Odinga, toured Atlanta during his trip to the United States to accept Kenya's new membership in the United Nations. ${ }^{31}$ According to Forman, Odinga's schedule, organized by the United States State Department, did not include a visit to SNCC's Atlanta office, "[s]o we decided to visit him." Forman recalled, "A group of us went to the Peachtree Manor where he was staying, brought him gifts, sang freedom songs and chanted 'Uhuru'-freedom-with him." Forman continued, "Inspired by the visit, we went on to a Toddle House restaurant for coffee." However, as the activists readily understood, the Toddle House was a racially segregated establishment. The Toddle House refused to serve the SNCC activists and Odinga, and twenty-one protesters, including members of the SNCC Freedom Singers and Atlanta office staff, were arrested. ${ }^{32}$ Odinga declared that American race relations were "very

30. "Atlanta," December 16, 1963, Forman Papers, Container 33, Folder Atlanta, 19631964; and Debbie H. Amis, "Atlanta," SNCC Papers, December 16, 1963, reel 37, frame 42.

31. "Kenya Leaders to See City Today," Atlanta Daily World, December 21, 1963, 1; and Harmon Perry, "Kenya Officials See Atlanta Area," Atlanta Daily World, December 22, $1963,1$.

32. Forman, The Making of Black Revolutionaries, 360-61. See also "Charles Cobb, Jr., From Atlanta to East Africa," in No Easy Victories: African Liberation and American Activists Over Half a Century, ed. William Minter, Gail Hovey, and Charles CobbJr. (Trenton: Africa World Press, 2008), 101; Julian Bond, "SNCC: What We Did," Monthly Review 52 (2000): 14; and Mary King, Freedom Song; A Personal Story of the 1960s Civil Rights Movement (New York: William Morrow, 1987), 164-69. 
pitiful" and proclaimed that the United States "practices segregationwhich is what we are fighting in Africa." 33

Matthew Jones, the SNCC Freedom Singer who penned the movement anthem, "Oginga Odinga," reflected on meeting the Kenyan revolutionary: "It's a funny thing about that word freedom. It doesn't make any difference if it's Swahili, Japanese, Chinese, English or French, it's got that certain ring to it. We ...thank Mr. Odinga for revitalizing the movement in Atlanta." 34 Embarrassed by the negative publicity surrounding the protests and arrests during Odinga's visit to Atlanta, Dobbs House, owner of Toddle House Restaurants, entered negotiations with SNCC, and subsequently desegregated all Dobbs House and Toddle House Restaurants nationwide. ${ }^{35}$

As the new year started, the independent-minded and energized student movement did not relent. On January 7, 150 demonstrators, under the guidance of SNCC and COAHR, "played hooky for freedom" to protest the "overcrowded conditions and inadequate facilities" in black Atlanta schools. ${ }^{36}$ The organizers maintained that in the spirit of the " 21 students [who] spent Christmas in jail to desegregate [the] Dobbs and Toddle Houses," students should "join the March on Atlanta [to] learn civics in the streets, history at the counters, and teach Mayor Allen democracy." 37 The group soon descended upon Mayor Allen's City Hall office and thereafter attempted to receive service at two segregated fast-food restaurants. ${ }^{38}$ Although there were no arrests during the march, eighty-nine students were suspended from school for their involvement. ${ }^{39}$ SNCC Chairman John Lewis was unapologetic about the students "playing hooky for freedom"

33. "Christmas in Jail," The Student Voice, December 23, 1963, 1; "Workers Spend Xmas in Jail," The Student Voice, December 30, 1963, 1; Forman, The Making of Black Revolutionaries, 360-61; and King, Freedom Song, 186.

34. Guy Carawan, Candie Carawan, and Julian Bond, Sing for Freedom: The Story of the Civil Rights Movement through Songs (Montgomery: New South Books, 2008), 124; and Harry Lefever, Undaunted By the Fight: Spelman College and the Civil Rights Movement, 1957-1967 (Macon: Mercer University Press, 2005): 172-75.

35. "Agreement Reached with Dobbs Houses," The Student Voice, January 14, 1963, 3. "James Forman editorial," March 6, 1964, Forman Papers, Container 33, Forman Papers, Container 33, Folder Atlanta, 1963-1964. See, generally, Forman Papers, Container 19, Folder SNCC Correspondence, January 1964.

36. In 1964 , activists cringed that there were 14,000 black students cramped into Atlanta's six segregated high schools, while 18,000 white students enjoyed the city's other eighteen high schools. More than 5,000 black elementary students in Atlanta were schooled in double sessions, yet fewer than 100 white elementary students in the city endured a double session. "Atlanta: Protests and Progress," March 27, 1964, Paschall Papers, Series 1, Box 6, Folder 1.

37. "Now Is The Time for Action," January 1964, SNCC Papers, reel 19, frame 105.

38. Grady-Willis, Challenging U.S. Apartheid, 44.

39. Harmon, Beneath the Image of the Civil Rights Movement, 156-57. 
and radically reframed the students' activism: it was his "feeling that most of the students involved will learn more in one day in a freedom school than they will learn in a whole year in a segregated school." Nevertheless, the mayor refused to meet with the students, whom he labeled "truants." 40 The Atlanta Daily World predictably voiced the conservative perspective within black Atlanta, contending, "With the dropout rate among teenagers at an all-time high, our students can ill-afford to flout discipline in the classroom and 'learn civics in the streets' or 'history at the counters." "41

The late December and early January, protests reflected the students' evolving political consciousness. As Ed Nakawatase, a JapaneseAmerican SNCC activist who spent 5 days in jail after he attempted to desegregate the Toddle House during Odinga's visit, remembered, "[T] here was a resonance with this leader of a newly independent African nation by most of my African-American comrades. The visit gave some reality to the notion that we were engaged in a ... larger international struggle." 42 Moreover, this alternative vision of freedom defied the demands of older civil rights leadership and their middle-class notions of public decorum. Few African-American professionals decried student activism at upscale hotels and restaurants. However, SNCC's protests at local diners and fast-food restaurants reflected their growing lack of concern with the conventions of black middle-class politics. ${ }^{43}$

Over the next several weeks, hundreds of high school and college students and local citizens were arrested on charges of disorderly conduct and trespassing. Inside segregated eateries, sit-in demonstrators braved restaurant waitstaff wielding butcher knives and baseball bats. They dodged the fists and bowls of condiments hurled at them. Police soon followed with bruising billy clubs and chokeholds. Protesters poured into the Fulton County Jail, only to be segregated by race again and endure renewed rounds of beatings - this time from hardnosed inmates. In January 1964, SNCC was revealing to the nation that despite Atlanta's liberal reputation, Jim Crow continued to undermine the life chances of black Atlantans. As a New York Times article noted, "The student committee has led virtually all the recent demonstrations that have marked a stepped up campaign by civil rights organizations for goals more extensive than those won by Northern Negroes. Those include broad-scale

40. Grady-Willis, Challenging U.S. Apartheid, 44.

41. "Action of Students Tuesday Deplorable," Atlanta Daily World, January 8, 1964, 3.

42. Interview with Ed Nakawatase, Charlottesville, VA (December 7, 2006).

43. Grady-Willis, Challenging U.S. Apartheid, 46. 
improvements in education, employment, health, government and public accommodations." 44

World audiences were also taking notice of Atlanta's winter of discontent. International media outlets in places as diverse as Toronto, Kingston, and Bombay covered the Southern capital's quickly escalating, racial crisis. SNCC's new offensive, according to the Indian newspaper, had even left some Klansmen with "cold feet." Rather than confront SNCC activists demonstrating outside of a segregated restaurant in January 1964, "ten robed members of the Ku Klux Klan had locked themselves in and with the lights turned off." Forman, the Indian Express reported, then "taunted the Klansmen through the closed doors." Such a confrontation would have been unimaginable to many black Atlantans only several years earlier. Forman announced to onlookers and readers, "The day has come when the Ku Klux Klan is afraid to come out."45

\section{Morris Abram and the Fight to Internationalize the First Amendment}

In the midst of this new wave of radicalized student activism, the Sub-Commission prepared to convene in Atlanta to learn more about American progress toward ending racial segregation. Mayor Allen welcomed the fourteen member Sub-Commission to Atlanta as a personal favor to Abram, a Georgia native and the sole United States expert on the Sub-Commission. ${ }^{46}$

Abram personified the interest convergence between the Cold War and moderate factions of the civil rights movement. ${ }^{47}$ Abram, an Air Force

44. Claude Sitton, "Negroes Resume Atlanta Sit-Ins after Sidewalk Clash with Klan," New York Times, January 20, 1964, 15; "Student Affidavits," Paschall Papers, Series 4, Box 25, Folder 2.

45. See " 17 Civil Rights Members Jailed in Georgia," Daily (Kingston) Gleaner, December 23, 1964, 12; "73 Arrested After Klan Sparks Fight," The (Toronto) Globe and Mail, January 20, 1964; "Klan's Cold Feet," The Indian (Bombay) Express, January 20, 1964, 5.

46. The U.N. GA had charged the Sub-Commission to draft an international convention, and the Sub-Commission began its work on ICERD on January 13, 1964. The U.N. instructed all Sub-Commission members to act in their own personal capacity, and accordingly, Sub-Commission members were prohibited from making official pronouncements on behalf of their countries. Nonetheless, the Sub-Commission's recognition of personal autonomy operated as a fiction in many instances, as the Sub-Commission was composed of racial "experts" appointed by their respective national governments. Lerner, The U.N. Convention on the Elimination of All Forms of Racial Discrimination, 1-4.

47. See Derrick Bell, Jr., "Brown v. Board of Education and the Interest-Convergence Dilemma," Harvard Law Review 93 (1980): 518; and Mary Dudziak, "Desegregation as a Cold War Imperative," Stanford Law Review 41 (1988): 61. 
Major during World War II, a staff member of the prosecution team at the Nuremberg Trials, and the first general counsel of the Peace Corps, understood that promoting civil rights at home would strengthen the United States's image abroad. In fact, President Kennedy had selected Abram for the Sub-Commission post, in part, because of Abram's willingness to tackle Jim Crow in Georgia. He had nobly fought to expand black voting rights and civil liberties in the Peach State, convinced Mayor Allen to testify on behalf of the bill that would eventually become the Civil Rights Act of 1964, and even helped engineer Dr. King's release from an Atlanta jail in $1960 .{ }^{48}$ But for Abram, like Kennedy, civil rights was not simply a moral issue. Civil rights was also a foreign policy issue. Jim Crow had undermined American attempts to win the Cold War. Demonstrating that United States officials were sympathetic to civil rights would allow the nation's diplomats to argue more persuasively that United States-style democracy was the model for foreign governments and the U.N. to follow. ${ }^{49}$ Accordingly, Abram, who served as the primary drafter of ICERD during the Sub-Commission's January 1964 session, acknowledged to his colleagues on the Sub-Commission that the United States still struggled with racism; however, he used the nation's growing commitment to formal equality during the civil rights movement to counter foreign criticism of American race relations. "I felt that... no matter how lax we were in enforcing [civil rights], we were without fault compared to the rest of the world," Abram remembered. ${ }^{50}$ "I was keenly aware that I was representing the only great power that stands for human rights, though the United States in the 1960 s took great abuse from quarters in which freedom and liberty were unknown." Abram believed that by showing the Sub-Commission the changes occurring in the civil rights South, he could "flaunt the glorious difference between [United States] society and that of a country such as the Soviet Union, whose vast engine of repression operates in the name of government." 51

48. "Interview of Mayor Ivan Allen," July 30, 1991, Gary Pomerantz Papers, MARBL, Series 1, Box 1, Folder 8 (hereafter Pomerantz Papers); "Interview of Leroy Johnson," September 12, 1994, Pomerantz Papers, Series 1, Box 4, Folder 9; "Interview of Leroy Johnson," n.d., Pomerantz Papers, Series 1, Box 4, Folder 10; and "Biography," n.d., Morris Abram Papers, MARBL, Box 22, Folder 12 (hereafter Abram Papers).

49. See Mary Dudziak, "Birmingham, Addis Ababa, and the Image of America: The International Influence of U.S. Civil Rights Politics in the Kennedy Administration," in Plummer, Window on Freedom, 181-83.

50. "Transcript, Morris Abram Oral History Interview II," March 3, 1984, Lyndon Baynes Johnson Library (hereafter Abram Oral History).

51. Morris Abram, The Day is Short: An Autobiography (New York: Harcourt, 1982), $150-51$. 
Abram hoped to reproduce Atlantans' respect for the First Amendment throughout the world. ${ }^{52} \mathrm{He}$ had devised the Sub-Commission's Atlanta visit- the group's first trip to the South and anywhere in the United States outside of the U.N. headquarters in New York for that matter-with this specific goal in mind. Atlanta's racial ambassadors would demonstrate that the city's transition away from Jim Crow was possible under a juridical framework, such as the First Amendment, which protected the rights of both civil rights organizations and hate groups. ${ }^{53}$ In turn, the Atlanta visit would persuade the Sub-Commission's members to trust that they could end racial discrimination by adopting a draft convention that was modeled on the United States's protections of freedom of speech and association.

Only weeks before the trip to Atlanta, however, the U.N. had ratified the Declaration on the Elimination of All Forms of Racial Discrimination, including its controversial Article 9 provision, which had tarnished the image of American democracy. Under Article 9, state signatories to the Declaration were urged to denounce "[a]ll propaganda and organizations based on ideas or theories of the superiority of one race and "prosecute and/ or outlaw organizations which promote or incite to racial discrimination." 54 Article 9 of the Declaration conflicted with the First Amendment's protection of hate speech and hate organizations, and the Soviets seized upon this apparent contradiction in United States constitutional politics; that a nation allegedly committed to improving race relations would legally protect the activities of hate groups. Thus, throughout the Sub-Commission's 1963 debates on this contentious provision, Boris Ivanov, in violation of the Sub-Commission's protocol, taunted Abram in front of the human rights community for the continued existence of Klan activity in the United

52. In a 1993 interview, Abram recalled, "I was serving in the Subcommission for the Prevention of Discrimination and the Protection of Minorities of the United Nations, and I was hearing so much static about what a terrible country we had and how dreadfully blacks were treated, and Atlanta was sort of a model." He maintained, "It hadn't been desegregated, but it was a model in terms of black voting, decent courts, fine universities, beautiful homes, and black prosperity." Abram Oral History, 6. The United States State Department's guidance paper to Abram for the Sub-Commission's 1964 session declared, "On the development of text, coverage should be limited to basic rights and the approach should be along the lines of the 'equal protection' concept in our 14th Amendment." The guidance paper also stated, "Provisions in line with the US Constitution and law should be supported on their merits. It can be pointed out that our Constitution is consistent with the Universal Declaration, which has been generally accepted as an international norm." "Guidance Paper, Draft Convention on the Elimination of All Forms of Racial Discrimination," January 7, 1964, Abram Papers, Box 94, Folder 3.

53. Guidance Paper, Draft Convention on the Elimination of All Forms of Racial Discrimination, see above, note 52.

54. Declaration on the Elimination of All Forms on Racial Discrimination, art. 9. 
States. Ivanov drew parallels between the United States's protection of hate speech and Nazi Germany's endorsement of anti-Semitism, emphasizing "the danger of allowing individuals and organizations to preach racism with impunity because, as experience,in Germany had shown, such license could not only affect State policy but might even become State doctrine. Hitler had actually converted the racist propaganda current in Germany before the second World War into official Government policy, with consequences which should not be permitted to recur." Ivanov then fanned the flames of the Cold War, sarcastically remarking, "He was confident, however, that Governments including the United States could take measures to close any loopholes in their legislation which might permit racist and fascist propaganda, without impairing freedom of speech." 55

Abram was livid. ${ }^{56}$ The Declaration's condemnation of both hate speech and hate groups had given moral weight to the Soviet Union's legitimate concerns that the continued activity of hate groups, such as the Ku Klux Klan, undermined black strivings in the Jim Crow South. Simultaneously, the Declaration rendered the United States's toleration of hate and, by extension, the American ideas of free speech and association, as racial outliers in global governance. The United States was humiliated by the Soviet bloc. American diplomats grumbled that they were unable to vote for a Declaration provision, "which if we were to implement it, would violate what our Constitution establishes as the inalienable rights of our citizens," and the State Department issued press releases across the globe attempting to explain the United States's seemingly lukewarm support for the U.N.'s fight to eliminate racial discrimination. ${ }^{57}$

55. Ivanov's scathing comments did not stop there, "Indeed, if the Sub-Commission failed to take any action against racist propaganda, it would be guilty of abetting it. Such propaganda, if fostered at the Government level, could lead to a situation as terrible as that which the world had witnessed in the days of Nazi Germany, and it must be banned." Ivanov maintained, "Some countries allowed fascist and racist meetings and demonstrations to take place on the grounds that to ban them would be a restriction of the freedom of the inhabitants, but allowing those vile doctrines to be propagated could not be called freedom." Sub-Commission on Prevention of Discrimination and Protection of Minorities, Summary Record of the Four Hundredth Meeting, E/CN.4/Sub.2/SR.400.

56. Abram confided in his close friend, Robert Thompson, "I must tell you frankly that I had quite a donnybrook with my Soviet counterpart and I am sure that he and I will continue to have very strong differences of opinion." Abram then began to strategize ways he could promote the foreign policy interests of the United States during future Sub-Commission debates. "Letter from Morris Abram to Robert Thompson," February 6, 1963, Robert Thompson Papers, Woodruff Library, Atlanta University Center, Series 7, Box 63, Folder 3.

57. See "Letter from Harlan Cleveland to Dean Rusk," October 16, 1963, Berl Bernhard Papers, John F. Kennedy Presidential Library, Series 1, Box 16, Folder-United Nations General GA Committee. 
Thus, in 1964, State Department officials considered the ban of hate speech and groups the "key section of the Draft Convention." 58 Abram remained optimistic that he would be able to use the Sub-Commission's ICERD debates to counter Soviet advances on the hate speech question. This new round of Sub-Commission debates was significant for several reasons. First, a convention, unlike a declaration, is legally binding upon state parties. Accordingly, the Sub-Commission's 1964 session provided Abram with an opening to translate American constitutional understandings of free speech into a binding international legal document. Abram recognized this substantial distinction early in these debates, arguing, "The declaration, however, is not offered as legislation and of course this was widely known to the Assembly when it was adopted. Now we are drafting a convention. It is not sufficient to merely lift clauses from the declaration and to rewrite the proclamations as commands." Abram stressed, "No convention is practicable which demands a serious abridgement of freedom of speech, since a significant part of the world enshrines this right as a cornerstone of its society. In these states certain individual rights are not merely well regarded; they are indispensable." 59

The Sub-Commission's 1964 session also offered Abram a second opportunity to win the ideological battle with the Eastern bloc over the racial efficacy of the First Amendment. During the Sub-Commission's 1963 session, the Soviets had successfully portrayed the First Amendment as a legal barrier in the worldwide march to eliminate all forms of racial discrimination. In 1964, State Department officials instructed Abram to emphasize that the American constitutional protections were consistent with human rights norms and that Article 9 of the Declaration and the provision that would become Article 4 of the Convention were deviations from longstanding human rights traditions. ${ }^{60}$ "[F]rom a reading of Article 19 and 20 of the Universal Declaration of Human Rights," Abram professed to the Sub-Commission early in the 1964 session, "I should have thought that freedom of speech, opinion, assembly and association was at least the goal of almost all of mankind." Abram's assertion was

58. "Letter from John Means to Morris Abram," March 15, 1965, Abram Papers, Box 94, Unnamed Folder; Guidance Paper, Draft Convention on the Elimination of All Forms of Racial Discrimination, see above, note 52.

59. "Statement of Morris B. Abram before Sub-Commission on Prevention of Discrimination and Protection of Minorities," January 13, 1964, Abram Papers, Box 94, Folder 9; Sub-Commission on Prevention of Discrimination and Protection of Minorities, Summary Record of the Four Hundred And Twenty-Fifth Meeting, U.N. Doc. E/CN.4/ Sub.2/L.408.

60. Guidance Paper, Draft Convention on the Elimination of All Forms of Racial Discrimination, see above, note 52. 
technically correct. His texualist reading of the Universal Declaration of Human Rights (UDHR), the U.N's first articulation of the rights endowed to all people, seemed to support the United States's position on hate speech and groups, and with the UDHR hailed as a founding document of the contemporary human rights community, the U.N. General Assembly (GA) endorsed the position that the UDHR should guide each U.N. organ's elaboration of subsequent human rights provisions, including the hotly contested article. "In any event a very large number of people have lived in stable societies under free speech for a very long time. On principle these people support the right of their neighbors to express ideas with which they and their government frequently disagree and which they occasionally find hateful," he continued. "They have learned from experience," Abram reasoned, "that this system which permits free speech is durable-far more so than some which tolerated no diversity of opinion."61

Abram, nevertheless, was unable to persuade the Sub-Commission that racial progress could occur under a legal regime that permitted the promotion of racist viewpoints. With the Sub-Commission largely unconvinced of Abram's position, the body, during the early 1964 debate, tentatively agreed on criminalizing hate speech and hate groups in the draft Convention. The State Department was particularly troubled by section (b) the proposed article. Under section (b), state parties to the Convention were to "declare illegal and prohibit organizations, and also organized and all other propaganda activities, which promote and incite racial discrimination, and shall recognize participation in such organizations or activities as an offence punishable by law." 62 The United States, despite Abram's impassioned advocacy, was, again, a racial outlier in the human rights community's stance on hate speech.

61. Ibid; Sub-Commission on Prevention of Discrimination and Protection of Minorities, Summary Record of the Four Hundred And Twenty-Fifth Meeting, U.N. Doc. E/CN.4/Sub.2/ L.408 and U.N. Doc. E/CN.4/Sub.2/SR.409.

62. "Statement by Morris B. Abram, United States Expert Member of the Subcommission on Prevention of Discrimination and Protection of Minorities, on the Draft International Convention on the Elimination of All Forms of Racial Discrimination," January 22, 1964, Abram Papers, Box 94, Folder 9. The United States position was that "while "promotion' [of racist propaganda] by state authorities may be prohibited, 'promotion' by private individuals may not be prohibited consistent." Ibid. See also "U.S. Position on Articles Adopted by the Commission at Its 1964 Session and on U.S. Proposal for Additional Article on Anti-Semitism and Soviet Amendment to that Proposal," May 12, 1964, Abram Papers, Box 94, Folder 9; and Statement by Morris B. Abram, United States Expert Member of the Subcommission on Prevention of Discrimination and Protection of Minorities, on the Subcommission's visit to Atlanta. 
Abram's response to the controversial provision was simple. With a week of Sub-Commission debates left, Abram hoped that the trip to Atlanta-c"the city too busy to hate"-would spur the Sub-Commission to reverse its position on the article and compel the U.N. experts to incorporate new, more robust protections of free speech and association in the draft Convention. Viewing the Southern metropolis first hand would make Abram's point in a way that sterile and far-removed, Sub-Commission debates in New York could never do. ${ }^{63}$ The State Department recognized this fact. "Delegates from other countries who have had the opportunity for first-hand observation in the South have usually been quick to support the United States in U.N. discussion of race problems," one official reminded Abram. ${ }^{64}$ Similarly, Abram declared, "The hope is that the visit will put in focus the uninformed impressions of some members about the South as a whole."65

\section{Local People, International Law}

In the days immediately preceding the Sub-Commission's tour of Atlanta in January 1964, civil and human rights watchers across the nation anxiously waited to see if Abram would be able to use Atlanta to impress the Sub-Commission and, more importantly, use the tour of the city to convince the Sub-Commission that it needed free speech and association provisions in the draft Convention. The Los Angeles Times announced, "A Southerner who is eager to prove the merits of free speech is taking a group of critical United Nations delegates on a tour of segregation-and integration-in Atlanta, Ga." Abram confidently asserted to the West Coast reporter that "Georgia's progress on racial integration will speak for itself." The article concluded, "He conceived of the trip himself, not to persuade his colleagues that all is well in Georgia, but to demonstrate the progress being made under American laws. In this way, the trip can be considered part of his argument to the subcommission that any conventions on racial discrimination must also include protections for freedom of speech." 66

63. "Letter from Morris Abram to Richard Gardner," January 23, 1964, Abram Papers, Box 94, Folder 9.

64. "Letter from Harlan Cleveland to Morris Abram," November 28, 1962, Abram Papers, Box 94, Folder 8.

65. "Letter from Morris Abram to Richard Gardner," see above, note 63.

66. Louis B. Fleming, "U.N. Critics of South to See Atlanta," Los Angeles Times, January $23,1964,1$. 
Other national newspapers highlighted the significance of Sub-Commission's trip to Atlanta. On January 23, the Washington Post reprinted the Los Angeles Times article and later noted that Abram devised the Atlanta trip to provide "insight into the American concept of democracy and freedom of speech." 67 The New York Times reported that Abram scheduled the Sub-Commission's visit to Atlanta "to observe the relationship between whites and Negroes" but also underscored that "students of the city's Negro colleges prepare[d] for a mass protest ... for the benefit of a visiting United Nations group."68 And the Atlanta Constitution, the South's largest and most influential newspaper, ran several articles covering Abram's attempt to change world opinion on the United States South. ${ }^{69}$ These national news accounts confirmed Abram's intentions to remake the Convention's most debated article in the image of the First Amendment of the United States Constitution. "It would be helpful if members were given a better appreciation of the way a free society adjusts to change," he wrote to State Department officials on the eve of the Sub-Commission's visit to Atlanta, "without a revision of its constitutional guarantees of free speech."70

Under Abram's leadership, the U.N. group visited the city from Friday, January 24 to Sunday, January 26, 1964 to observe "how a democratic nation wrestles with its problems." " He reiterated that he had "no intention to portray Atlanta or any part of the U.S. as a model community." Nevertheless, his selection of Atlanta over other Southern cities, such as Jackson, Mississippi, or Birmingham, Alabama was clearly a strategic choice aimed to advance American foreign policy interests during the Sub-Commission's ICERD debates. ${ }^{72}$ "In Atlanta," Abram emphasized,

67. Louis B. Fleming, "U.N. Critics of South to See Atlanta," Washington Post, January 23, 1964, A24; and B. Drummond Ayres Jr., "Commission on Racial Discrimination Impressed by Negro Student Protest," Washington Post, January 28, 1964, A2.

68. Sitton, "Negroes Resume Atlanta Sit-Ins after Sidewalk Clash with Klan," 15; see also Kathleen Teltsch, "Pact to Ban Bias Proposed in U.N.," New York Times, January 14, 1964, 7.

69. "Abram Asks World Ban Against All Racial Bias," Atlanta Constitution, January 14, 1964, 2; "Abram Will Bring U.N. Board on Bias to Atlanta Friday," Atlanta Constitution, January 23, 1964, 5; Eugene Patterson, "To Atlanta's U.N. Visitors," Atlanta Constitution, January 25, 1964, 4; and "U.N. Board Arrives to Examine Bias," Atlanta Constitution, January 25, 1964, 3.

70. "Letter from Morris Abram to Richard Gardner," see above, note 63.

71. Baskt, "Atlanta," 1.

72. Abram wrote to one of his colleagues, "This week-end I am taking, a U.N. Sub-Commission group, on which I sit, to Atlanta, Georgia for a visit and have, therefore, been talking to Negro leaders in the South. Through these conversations, I have become concerned about the problem in Birmingham which is smoldering and can easily erupt in a serious form without notice. ...I am sure that the last thing any of us would want prior to 
"the members of the Subcommission will see a southern city which has made great strides and continues to do so in the areas of human relations." 73 For Abram and many other Cold War liberals, Atlanta was an ideal city for a State Department-sponsored visit to the United States, because Atlanta, renowned for its spirit of biracial communication among business-oriented, racial moderates, seemed to embody American exceptionalism and exemplify much-needed progress in Southern race relations. In a letter inviting Jose Ingles, the Filipino expert on the Sub-Commission, to Atlanta, Abram bragged of the Georgia capital, "One of the most notable circumstances ... is the remarkable development in the field of housing available to members of the Negro race. There are literally scores of new, fine and tasteful homes, I think probably without parallel elsewhere." 74 Abram's letter also highlighted that "Atlanta [had] just elected a Negro to the Georgia Senate, the first to serve since Reconstruction" and boasted that the city was "a center of Negro education; there are five accredited universities and colleges there, perhaps the greatest complex of its type in the world." 75 During the Sub-Commission's ICERD debates, Soviet racial experts repeatedly rebuked American officials for allowing rabid segregationists to assail nonviolent demonstrators and for failing to ensure the economic, social, and cultural rights of black Southerners. Abram was hopeful that Atlanta's well-publicized history of interracial cooperation, extensive network of historically black colleges, and remarkable stock of housing for the black bourgeoisie would give State Department officials the ideological

November 1964 is for the President to face the choice of whether or not to send troops into Birmingham." "Letter from Morris Abram to William D. Moyers," January 22, 1964, Abram Papers, Box 32, Folder 11. "While no one will pretend Atlanta is the same as Jackson, Mississippi, too often the outside world knows little of the differences." "Letter from Morris Abram to Richard Gardner," see above, note 63.

73. While the State Department endorsed the Sub-Commission's Atlanta visit, the trip was privately financed. "Statement by Morris B. Abram, United States Expert Member of the United Nations Subcommission on the Prevention of Discrimination and Protection of Minorities, on the Subcommission's visit to Atlanta," January 1964, Abram Papers, Box 94, Folder 9.

74. "Letter from Morris Abram to Honorable Jose D. Ingles," December 4, 1962, Abram Papers, Box 94, Folder 8. But also, see Brown-Nagin, Courage to Dissent, 59. Brown-Nagin, citing a 1959 United States Civil Rights Commission hearing held in Atlanta, depicts the city's housing stock for blacks otherwise. She writes that at the turn of the decade, "African Americans made up more than a third of Atlanta's population, but were 'compressed' into less than one-sixth of the city's developed residential areas. Many blacks lived in overcrowded, dilapidated homes, amid squalid conditions."

75. "Letter from Morris Abram to Honorable Jose D. Ingles," December 4, 1962, Abram Papers, Box 94, Folder 8. 
weaponry they needed to counter Soviet attacks on the racial economy in the United States South; these features of Atlanta "never failed to bring rather surprised comment from outside visitors." 76

State Department officials were not alone in understanding the importance of Atlanta in the Sub-Commission's debates. Many Atlantans, themselves, recognized the city's central role in the Sub-Commission's affairs, because of local media's extensive coverage of the U.N. organ in January 1964. Throughout the month, both the Atlanta Constitution and the Atlanta Daily World repeatedly touted Abram's connection to the city as a "former Atlanta attorney," and identified the homegrown diplomat as the primary drafter of ICERD. One January 1964 Constitution article, for example, announced that Abram, the "Atlanta-born New York attorney who has been the U.S. expert on the subcommission for the last three years," had presented "a sweeping international treaty" to the U.N. body. The article continued, "Abram proposed eight articles for the treaty and said a ninth-aimed at hate groups would be added after he works out more exact language." Local media had also illuminated the global significance of the U.N. delegation's Southern expedition. On the eve of the Sub-Commission's visit, Eugene Patterson, editor of the Constitution, authored a strongly worded column to "Atlanta's U.N. Visitors," mirroring Abram's faith that Atlanta would improve international perceptions of racial politics in the United States. "To the United Nations Subcommission on the Prevention of Discrimination and Protection of Minorities: Welcome to Atlanta. You will find no better American city to observe," the self-assured, editorialist wrote. "Race relations here aren't as good as they ought to be," he added, "but they may be better than some citizens of your homelands have thought." Patterson, "genuinely proud" of the city's racial progress, hoped that the U.N. experts would view America's commitment to democracy through the prism of Atlanta's ostensible respect for human rights. "As a city representing the United States of America," the Constitution journalist and Abram ally puffed, "Atlanta welcomes your appraisal." "In Atlanta, justice will be done. We would like the world to know it, for liberty and justice to all is a living American ideal."

Although Abram claimed that he did not intend to showcase Atlanta as a "model community," he had actually cancelled the Sub-Commission's planned trip to the city in January 1963 due to a local racial catastrophe that attracted international attention. As wealthy black Atlantans began to shop for new homes in exclusive areas of the southwest city, blockbusting convinced Mayor Allen to erect concrete barriers to limit traffic flow to

76. Ibid. 
these areas. Specifically, city planners blocked access to the affluent white, Cascade Heights neighborhood from Peyton Road, a thoroughfare frequently travelled by black home-seekers. ${ }^{77}$ Black Atlantans were furious. Aspiring black homeowners and activists alike, clad in conservative dark suits and Sunday morning dresses, exposed the racial fault lines of the Cold War America by sending the world iconic images of sympathetic protesters carrying signs, reading, "Atlanta's Image a Berlin Wall" and "We Want no Warsaw Ghetto-Open Peyton Road."78 The "Peyton Road Affair," as it came to be known, "caused [Abram] to make an excuse for the committee not to go" to Atlanta. Abram subsequently rescheduled the Sub-Commission's tour for January 1964, hoping that "there would be no mass movements in Atlanta until after February 1, 1964, when the weather would be more favorable and students had finished their semester examinations."79

Moreover, despite Abram's assertion that Atlanta officials "have nothing to hide" from the Sub-Commission, he and Mayor Allen, in the city's ritual of easing racial tension through brokerage, spoke with local black leaders to ask that no protests occur during the Sub-Commission's visit ${ }^{80}$ During this period of radicalization, SNCC activists were emboldened to continue their demonstrations anyway, even if it would, in the mayor's eyes, "embarrass the city while the U.N. was in town." In the spirit of this newly emerging militancy, Julian Bond, the velvet-voiced communications

77. See generally Curry Papers, Series 3, Box 9, Folder 10; Forman Papers, Container 33, Folder Atlanta 1961-1962; Pomerantz Papers, Series 1, Box, 5, Folder 7.

78. "Letter from Robert Thompson to Morris Abram," February 4, 1963, Abram Papers, Box 94, Folder 8. Thompson wrote Abram, "As much as I would love to see you and the U. $\mathrm{N}$. groups come to Atlanta to view racial amity, I think the hotel situation and the Peyton Road barriers would be most embarrassing to you, Atlanta and America." Thompson also asserted that the "closing of Peyton Road ... is considered as a 'Berlin Wall' which we all are ashamed. So, until the Alderman Board recinds [sic] its action, by ordering the barriers along Peyton Road taken down, I think that you would be embarrassed." Ibid. In 1963, the Fulton County Superior Court ordered the wall to be taken down, but well before the court order, even white moderates in Atlanta, recognizing the Cold War implications of the barriers, called for the wall to come down. In a 1962 editorial, Ralph McGill, publisher of the Atlanta Constitution, wrote, "The Chinese once labored for decades to build a wall to keep out invaders. France built the Maginot Line to restrict the Germans. The Communists built the Berlin wall. The Atlantans who erected the wooden screen have done themselves, their city, and their country a great deal of harm." Ralph McGill, "The Folly of Barriers," Atlanta Constitution, January 27, 1962. See, generally, Abram Papers, Box 63, Folder 3.

79. "Morris Berthold Abram, FBI Special Inquiry," March 2, 1965, Abram Papers, Box 80, Folder 6; "Letter from Morris Abram to Richard Gardner," see above, note 63.

80. B. Drummond Ayres Jr., "Klan, Marchers Keep Atlanta Tense," Washington Post, January 25, 1964, A2; Sitton, "Negroes Resume Atlanta Sit-Ins after Sidewalk Clash with Klan," 15. 
director of SNCC, retorted to Mayor Allen, "But it would embarrass us not to have the demonstrations." 81

Undeterred by charges that the campaign was "inspired by communists," SNCC activists aimed to make segregationists "squirm" by showing that Atlanta was not the "progressive Southern city" city officials held it out to be. The student organizers, well known for their guerrilla tactics, somehow learned the unpublished itinerary of the Sub-Commission and seemed to ambush the international delegation and their local hosts at every turn. Picketers met the Sub-Commission as they arrived at Municipal Airport and at the Riviera Hotel, where the Sub-Commission was staying, holding large placards that declared, "Atlanta's image is a fraud" and "Welcome to Atlanta, a Segregated City." 82

SNCC also delivered an individually addressed letter to each Sub-Commission member's hotel room. The letter, echoing the sentiments from the demonstrations that greeted the Sub-Commission, stressed, "We are interested that you get a realistic view of this city and the South." SNCC's memorandum asserted that Atlanta was not the "Open City" its political and business leaders claimed it to be and that "this city, and the South, needs [the Sub-Commission's] aid and that of the United Nations." The letter maintained that although the most recent direct action had focused on integrating public accommodations, SNCC's campaign sought to secure "the rights America guarantees to all of her citizens, [including] the right to vote, the right to earn a decent living, to buy a home where he chooses, or to send his children to a decent school." The activists concluded, "Attempts at voluntary integration or voluntary compliance with the law of the land have failed. We are convinced that such pressures must continue until all men are equal here and across the South." 83

SNCC then distributed protest literature throughout the local community to explain the organization's rationale for targeting the U.N. experts for demonstrations and the significance of that January's "militant nonviolent direct action." One leaflet, entitled "Why We Protest," opened, "We welcome the United Nations [Sub-Commission] on the Prevention of Discrimination and Protection of Minorities to Atlanta, although a visit to southwest Georgia might have proved more revealing. Nevertheless there is much to be seen in Atlanta." In the leaflet, SNCC repeated its claim that Atlanta had "failed to live up to its image as a progressive

81. Baskt, "Atlanta," 4.

82. Forman, The Making of Black Revolutionaries, 361; "SNCC Backers Here Once Identified as Reds," February 2, 1964, Forman Papers, Container 84, Folder FBI Files, 1963-65.

83. "United Nations Sub-Commission on the Prevention of Discrimination and Protection of Minorities," January 24, 1964, SNCC Papers, reel 1, frame 31. 
city 'too busy to hate," and attacked the city's segregated public accommodations, "the impressions scarred deep in children's minds by inadequate and restricted education" in Jim Crow schools, and the continued existence of "those who would beat demonstrators or don the archaic cloth of the Ku Klux Klan." "Why We Protest" then exposed a deep irony underlying the recent prosecutions of the city's activists: "Atlanta has now assigned Negro policemen to supervise demonstrations and arrest demonstrators - but why is it only to watch over and arrest his brother that a Negro officer of the law is assigned downtown." The budding internationalists from SNCC, carefully positioning their local activism within the American tradition of patriotic dissent and the global struggle to end racial discrimination, proclaimed, "We have no shame in showing the world the truth, for we are acting out of the strongest belief in American democracy and the knowledge that Justice and Freedom are real and can be for all people." 84

Another SNCC flyer aimed at the Sub-Commission underscored to the stark economic conditions facing poor black Atlantans living in litter-lined neighborhoods such as Buttermilk Bottom. "Located in the heart of downtown Atlanta is the teeming slum of Buttermilk Bottom," the circular read. "Over 16,000 people live in the Bottom on a median income of below $\$ 2,500$ a year. That is poverty. The city of Atlanta has forgotten its poor." The flyer charged that the Bottom had "witnessed virtually no improvement in the last 50 years." Moreover, the city perpetuated this injustice by denying Bottom residents access to basic municipal services, resulting in unpaved and unlit streets, uncollected garbage, cold and dilapidated homes rented in violation of local housing codes, and "dirt roads [that] become rivers of mud" after rainfall. SNCC resolved, "If we are to be so proud as to invite international delegates to the clean white buildings of Peachtree Street then we must be honest enough to pave the streets of the Bottoms of Atlanta." 85

But Abram moved quickly to ensure that the members of the Sub-Commission would not have the ability to communicate directly with SNCC activists on the state of local or global race relations. He refused to invite members of the Atlanta student movement to participate in the weekend's events, instead filling the Sub-Commission's agenda with local black leaders who were willing to denounce the student protests and promote the goals of Abram's mission. On the day before the international delegation trekked to Atlanta, Abram wrote to State Department officials, "The top Negro leadership of the city will be quite hospitable."

84. "Why We Protest," January 24, 1964, Abram Papers, Box 94, Folder 9.

85. "Buttermilk Bottom," January 1964, Abram Papers, Box 94, Folder 9. 
He maintained, however, "There is a distinct possibility that members of the Student Non-Violent Coordinating Committee will be demonstrating in Atlanta, but they will receive no support as such from the broad spectrum of Negro leadership." 86

From the moment Sub-Commission arrived Atlanta on Friday evening, elite black Atlantans, handpicked from Abram's personal rolodex, used their world stage to offer crass endorsements of the city's race relations and the views Abram expressed during formal Sub-Commission meetings. Robert Thompson, Executive Director of the Atlanta Urban League and confidant of Abram, kicked off a weekend of turbulence by claiming that the Sub-Commission would see "democracy at work" in Atlanta. "You will see students demonstrating or saying, in effect, they do not like this or that. This, in my opinion, is freedom of speech, and we think this is very important in this kind of country." Thompson paused and his creaking voice then deepened in rasp. "I'm sorry that Mayor Allen is not here," he half-heartedly apologized to the Sub-Commission, "because I would say to him that as a member of the minority, I still have the right to say to Mr. Allen, 'You may go to hell,' if he were to do something I don't like." Thompson's oddly timed and clumsily worded declaration filled the room with an uncomfortable silence; however, he prolonged the gauche moment. "I can still say to the President of the United States, 'You go to hell, I don't like what you're saying," Thompson muttered. ${ }^{87}$ Paul Good, an $\mathrm{ABC}$ journalist covering the Sub-Commission visit, aptly characterized Thompson's crude remarks as "an unfortunate speech, the kind of declaration made by men who have lived under unnatural tensions all their lives and in a moment of release are carried too far by the momentum of long-bottled emotion." Thompson analogized his bumbling pronouncement to the students' intrepid exercise of the First Amendment, but the Sub-Commission remained unmoved by the Host Committee's heavy-handed tactics. ${ }^{88}$

On the following day, Saturday, January 25, Abram again asked the student activists to cease all protests, asserting that the Sub-Commission's task of drafting a convention to eliminate racial discrimination had "nothing to do with any grievances [SNCC] may have." 89 SNCC,

86. "Letter from Morris Abram to Richard Gardner," see above, note 63.

87. "Robert A. Thompson, Executive Director of the Atlanta Urban League, speaking to the United Nations Sub-Commission on the Prevention of Discrimination and Protection of Minorities at the Rivera Motel, in Atlanta, Georgia," January 24, 1964, Good Papers, Georgia CDl.

88. Ibid., Paul Good, The Trouble I've Seen: White Journalist, Black Movement (Washington, DC: Howard University Press, 1975): 42-43.

89. B. Drummond Ayres Jr., Klan, "Atlanta Rights Pickets Welcome U.N. Visitors," Washington Post, January 25, 1964, D12. 
nonetheless, rallied nearly 300 students, an unexpected greeting for the Sub-Commission members emerging from a private luncheon and briefing at the Atlanta University Center complex. A Washington Post beat writer relayed, "As the experts walked past, the students broke into 'freedom' songs, to the accompaniment of clapping hands and bongo drums." The Atlanta Hospitality Committee attempted to push its U.N. guests through the protest; however, several of the Sub-Commission members, including Soviet expert Ivanov and Chilean expert and Sub-Commission Chairman Hernan Santa-Cruz, lingered in the crowd because of their burgeoning interest in the SNCC demonstration.

“'What are they singing?' a Soviet member of the commission asked a student.

'Freedom songs,' the student replied.

'Ah, freedom,' the Russian said quietly to himself. Then he turned to another commission member and talked of the placards the students were carrying. One read, 'Atlanta Needs U.N. Help."'90

Following the Atlanta University Center (AUC) rally, SNCC marched a swelling throng of 400 students 2 miles in lines of two to an area near the restaurant where the Sub-Commission's had just dined with Mayor Allen. Once the protesters reached downtown, they poured into Leb's, a New York-style delicatessen that had refused to desegregate, unlike several of its neighboring restaurants. ${ }^{91}$ When owner Charles Lebedin arrived at the demonstration, he quickly closed the restaurant and asked two black police officers to arrest the sit-in activists. The police officers, however, perhaps seeing the irony of arresting organizers working on their behalf, refused Lebedin's request and cited their need to have a warrant demonstrating just cause. A stalemate between Lebedin and SNCC ensued, and over the next few hours, the number of student protesters dwindled to approximately 100 . Grand Dragon Calvin Craig subsequently summoned a group of Klansmen, who had been protesting desegregated downtown hotels and restaurants, and Craig arrived at Leb's with twenty robed Klansmen to intimidate the marchers. Undaunted by the Klan's presence, some SNCC protestors chanted, "The old KKK ain't what it used to be," while others shouted, "The KKK must go!"92

90. Ayres, "Commission on Racial Discrimination Impressed by Negro Student Protest," A2.

91. "Mass Rally, The Face of Atlanta-Help Change It," January 25, 1964, Abram Papers, Box 94, Folder 9.

92. Claude Sitton, "Negroes and Klansmen Clash in Atlanta as U.N. Group Visits City," New York Times, January 26, 1964, 1; see also Grady-Willis, Challenging U.S. Apartheid, 46- 47 . 
SNCC's otherwise peaceful march ended when the Klansmen began filing between the lines of the demonstrators. Pushing quickly followed and fistfights erupted thereafter. During the clash, at least two whites were visibly injured, one with a bruised forehead and another with a bloody nose. Although fifty police officers, most of them black, dispersed the crowd, ending "the most 'volatile' civil rights activity in the city in years," no one was arrested. ${ }^{93}$

The students' forceful responses to the Klan's intimidation were not meaningless acts of racial violence. During its tumultuous visit to Atlanta, Sub-Commissioners had been impressed by their local hosts but had also witnessed deeply conflicting accounts of America's racial problems and proposed solutions. The Sub-Commission had feasted on the Southern hospitality of liberal white Atlantans, such as George Goodwin, Henry and Adah Toombs, ${ }^{94}$ and Cecil and Hermione Alexander, ${ }^{95}$ all of whom supported desegregation. The U.N. experts additionally heard from more moderate white leaders, such as Ralph McGill, publisher of the Atlanta Constitution, whose newspaper reprimanded the student activists during the recent wave of protests for their use of the "dangerous and utterly cynical tactic of deliberate provocation." 96

The Sub-Commission also listened to the concerns of Atlanta's established black leadership, who "believed that there had been progress in solving the race problem in their city, "but hoped that further progress could be more rapid." 97 Despite the persistence of Jim Crow, the Sub-Commission lodged in a desegregated downtown hotel, sipped tea

93. "Police Arrest 84 in Atlanta Bias Protest," Chicago Tribune, January 27, 1964, 9. The 84 arrests described in the article headline refer arrests following Sunday's continued demonstrations. See also Claude Sitton, "Negroes and Klansmen Clash in Atlanta as U.N. Group Visits City," New York Times, January 26, 1964, 1. The student activists astutely understood the contradiction of having black police officers patrol the downtown direct action campaign. In the leaflet entitled "Why We Protest," SNCC asserted, "Atlanta has now assigned Negro policemen to supervise demonstrations and arrest demonstrators-but why is it only to watch over and arrest his brother that a Negro officer of the law is assigned downtown." "Why We Protest." see above, note 84 .

94. "Letter from Morris Abram to Mr. and Mrs. Henry J. Toombs," February 5, 1964, Abram Papers, Box 94, Folder 9.

95. "Letter from Morris Abram to Mr. and Mrs. Cecil A. Alexander," January 28, 1964, Abram Papers, Box 94, Folder 9.

96. Ralph McGill, "For a Public Accommodations Law; Against This SNCC-Led Lawlessness," Atlanta Constitution, January 21, 1964, 4.

97. "Chairman Sees Hope for Improvement of Relations in Georgia City After Visit," Washington Post, January 27, 1964, A2; and "Hospitality Committee for the United Nations Delegations, Inc.," January 1964, Abram Papers, Box 94, Folder 9. For a full list of the participants, see "Schedules," January 1964, Abram Papers, Box 94, Folder 9. 
and coffee in the lavish home of black entrepreneur, Geneva Haugabrooks, ${ }^{98}$ enjoyed elegantly catered dinners in interracial settings, and toured "the fantastic development of private housing in Negro communities in the western section of Atlanta." 99 The Atlanta Hospitality Committee had delighted the Sub-Commission's members in the pleasantries of the South, and in these social gatherings, the local hosts had intentionally surrounded the racial experts from the U.N. with elite black Atlantans well-schooled in "respectable" racial etiquette. Abram understood that the city's black brokers were essential to showing the world that Atlanta, the South, and the nation were at the vanguard of global progress toward ending racial discrimination. The group's high socioeconomic status, "racially authentic" voices, and measured assessments of white supremacy would dampen the negative impact of local student activism and demonstrate "progress being made there under democratic procedures." 100

In contrast to many of the black elders in Atlanta, the brazen student organizers used their violent confrontations with the Klan as "an opportunity to dramatize their cause," and these demonstrations made an indelible impression on the Sub-Commission. George Goodwin, Chairman of the Atlanta Hospitality Committee, remarked, "As nearly as I can tell, the only possible disappointment expressed by any of the Subcommission members was the fact that they were not driven down West Peachtree Street through the demonstration when they left Mayor Allen's dinner on Saturday night. I wonder if they understand that this was for their own safety." Goodwin estimated that the "scuffle between the Klan and the pickets broke out" only "two or three minutes" after Sub-Commission's bus left the dinner. He concluded, "Had the UN bus gone via West Peachtree, it would have been at that exact minute, in the midst of the most dangerous situation Atlanta has had in half a century."101

Because many Sub-Commission members felt that they had been shielded from the controversy in Atlanta, they asked to meet with student demonstrators, and a meeting was hastily arranged at the Butler Street YMCA only hours before the Sub-Commission's departure. Dick Gregory and James Forman represented SNCC at this impromptu session. Gregory, gifted with a searing sarcasm and known for his blistering critique of white

98. "Letter from Morris Abram to Mrs. Geneva Haugabrooks," February 5, 1964, Abram Papers, Box 94, Folder 9.

99. "Letter from Morris Abram to Honorable Ivan Allen, Jr.," January 6, 1964, Abram Papers, Box 94, Folder 9; "Letter from Morris Abram to Honorable Ivan Allen, Jr.," October 23, 1963, Abram Papers, Box 94, Folder 9; Abram Oral History, 7.

100. "Letter from Morris Abram to Richard Gardner," see above, note 63.

101. "Letter from George Goodwin to Mary Misch," January 31, 1964, Abram Papers, Box 94, Folder 9. 
supremacy, declared to the Sub-Commission, "The Negro in this country has a callous around his soul and is anxious to get rid of it."102

As the Sub-Commission prepared to leave Atlanta, the Sub-Commission held a brief press conference and there began to deviate from the polite script that had characterized the weekend's interactions between the Atlanta hosts and the Sub-Commission. Judge Mohammed Mudawi, the Sub-Commission member from the Sudan, offered a simple, yet profound assessment of the racial politics in the Southern city. Although he had hope for future change, Mudawi proclaimed to Atlanta and United States officials, "You have a big [racial] problem." Ivanov stoked the flames of the Cold War during the press conference by implying that Atlanta's race relations were far from exemplary. For Ivanov, the Sub-Commission's turbulent weekend in Atlanta was a part of a larger pattern of racial unrest in the United States, as "he had seen similar demonstrations in New York."103

Notably, after Ivanov's visit to Atlanta, Moscow began to pay close attention to Atlanta's unfolding racial strife. Pravda, the official publication of the Soviet Communist Party, even reprinted a photograph of 17-year-old SNCC activist Taylor Washington being strangled by an arresting officer during Atlanta's early winter demonstrations. This iconic image of police brutality in Jim Crow America - the frail-framed, boyish-faced high schooler wriggling for air and easily overpowered by a brawny, stoic, and unnamed embodiment of white supremacy-was captioned "Behind the Façade of the Free World." Pravda depicted Washington's personal struggle to survive the officer's vicious chokehold as a metaphor for the movement's struggle to preserve black humanity. The photograph's byline, translated from Russian, accordingly read, "Thus, in the U.S. they attempt to suffocate the struggle of the Negro people for freedom."104 The battle for desegregation in Atlanta had become new fodder for Soviet propaganda. The city's weekend of protests also aroused the passions of Santa Cruz, the Chilean expert and Chairman of the Sub-Commission. Santa Cruz argued that although "there was a sizeable group of 'progressive' whites in Atlanta who wanted to end racial discrimination," there remained

102. Claude Sitton, "6 in Atlanta Hurt in Racial Clashes," New York Times, January 26, 1964, 1; "Progress Being Made in Atlanta," Atlanta Daily World, January 28, 1964, 1; and Oswald Sykes, "Writer Calls Atlanta 'Hell Hole of the South," Herald-Dispatch, January 28, 1964, 1 .

103. "African Says U.S. Race Situation a Big Problem," Los Angeles Times, January 27, 1964, 16.

104. "Behind the Façade of the Free World," Pravda, March 4, 1964, 3 (citing James Williams, "Gregory Tells Judge Inmates were Drunk, Molested Girls," Afro-American, February 8, 1964, 1). The Afro-American article detailed the SNCC activists' allegations that they not only faced brutality during arrests but also suffered indignities while in jail. 
"great possibilities for improvement of relations" in Atlanta."105 Santa Cruz was well aware of the implications of the Sub-Commission's trip to the Jim Crow South. Although Abram had publicly claimed that the "Sub-Commission ha[d] no agenda in Atlanta," the Sub-Commission's Chairman stated otherwise. "I am sure what we have seen and heard will be of great help in the work we are doing," Santa Cruz predicted. ${ }^{106}$

Abram's plan had misfired. The Atlanta tour had not changed the Sub-Commission members' positions on banning hate speech and groups. Abram told reporters after SNCC's Saturday afternoon protests at the Atlanta University Center, "Ever since I've been on the commission, the biggest fight I've had is to make sure that any covenant we decide upon includes the American concept of freedom of speech." Abram, seeking to salvage a crumbling diplomatic effort and keep face before the human rights community, maintained, "It's hard to sit in the formal atmosphere of a U.N. conference room and make that point. Perhaps these demonstrations will bring it home."107

Many others, locally, nationally, and internationally, offered a different take on the late January weekend. ABC News Southern bureau chief, Paul Good, for example, called the weekend "bizarre" and wrote that the Sub-Commission "possibly could have been invited at a worse time, but no Atlantan could imagine when that might have been, except in 1864 when Sherman burned the city." According to Good, Abram recognized that the SNCC protests had botched his diplomatic mission, and throughout the turbulent weekend, he "wore the air of a man who had mistakenly invited a ladies' garden group to visit a bordello."108

The Washington Post wrote that the Atlanta Host Committee was mortified by the SNCC-led exercise in international diplomacy, because the student demonstrations "provided an insight into the American concept of democracy and freedom of speech" that Abram and local leaders had not "originally planned." The Host Committee had hoped to exclude SNCC from the weekend's agenda, because the students, they feared, might attempt to blot the city's reputation through their creative forms of dissent. The Host Committee's fears soon materialized. By the second day of Sub-Commission's tour, city officials had begun to "view [] the demonstrations and arrests as embarrassing," the Washington Post noted. City officials also publicly worried that the student protests posed "possible

105. See above, note $97, \mathrm{~A} 2$.

106. See above, note 103 .

107. Ayres, "Commission on Racial Discrimination Impressed by Negro Student Protest," A2.

108. Good, The Trouble I've Seen, 42-43. 
danger to the U.N. group itself, since many of the placards referred to the city's promoting of the visit." But the international delegation, unlike the Host Committee, neither found the members of the Atlanta student movement personally threatening nor chastised the students for their radical protests. Instead, the Post maintained, "the Commission on Racial Discrimination [was] impressed by the Negro student protest." An emotionally charged and rather undiplomatic outburst from the Sub-Commission's chairman, of all people, epitomized the Sub-Commission's newfound affinity for the Atlanta student activists. As the Sub-Commission exited Saturday's luncheon and briefing at the Atlanta University Center, Santa Cruz was overwhelmed by the swelling crowd of young revolutionaries clapping their hands and playing bongo drums to the rich Southern rhythms of freedom songs. "Several of the U.N. representatives paused" to hear SNCC singing, the Post article stated, "despite efforts of their hosts to push on." The article continued, "But it was the chairman of the commission, Hernan Santa Cruz of Chile, who seemed most of all to understand the freedom-of-speech implications of the singing. He joined in for a few verses of 'We Shall Overcome."' 09

The cultural and political significance of this particularly moving moment-located at the crossroads between extraparliamentary activism and international lawmaking-was not lost on black America. Jet Magazine proudly covered the Sub-Commission's historic visit to Atlanta and SNCC's critical intervention in the State Department's representation of domestic race relations. "The Sub-Commission was impressed by the massive protests, the civil disobedience (going limp), and especially the hand-clapping and freedom songs," the prize-winning weekly proclaimed. The student demonstrations had been so evocative that "[o]ne visitor requested that the students sing "We Shall Overcome."'110

Media outlets across the globe broadcast the racial strife smoldering in the streets of Atlanta. Newspapers throughout Africa covered the mass arrests that followed the racial confrontations at Leb's - "a colour bar incident at a whites-only restaurant," and according to one African daily, during these demonstrations, "the city too busy to hate" had transformed into a "racially tense city." In these accounts stretching the continent, from Lagos to Kampala, African journalists underscored the level of police brutality civil rights activists endured. "James Forman, an official with the Student Non-Violent Coordinating Committee was taken to the hospital with a back injury," both the West African Pilot and Uganda Argus

109. Ayres, "Commission on Racial Discrimination Impressed by Negro Student Protest," A2.

110. "Demonstrators Jamming Atlanta's Jails," Jet Magazine, February 13, 1964, 9. 
reported to their newly independent readerships, because "he was 'kicked and dragged' to a police car."111 Similarly, news of the Atlanta demonstrations and arrests circulated the Pacific world. Singapore's Strait Times described the "café clash" between "[w]hite-robed $\mathrm{Ku}$ Klux Klansmen [who] packed the restaurant [and] Negroes [who] paraded outside in protest," 112 while Sydney's Morning Herald and Melbourne's The Age observed that dozens of black protesters had arrested in Atlanta, including "Negro comedian Dick Gregory."113 In Europe, unflattering press coverage of the Atlanta protests was not relegated to the periodicals produced by the Eastern bloc; this news also blanketed Western Europe, from Glasgow to Geneva. ${ }^{114}$ In Dublin, for example, the Irish Times tagged the SNCC demonstrations as the "Racial Clashes in Atlanta." The Protestant nationalist organ then began its news story on the demonstrations in a manner unlikely to delight the State Department or the Atlanta Host Committee: "A United Nations subcommission probing discrimination, wound up its visit to Atlanta, Georgia, yesterday in the wake of disorders during the night between Negro students and Klu [sic] Klux Klansmen."115

Even the United States' neighbors grabbed readers' attention through sensational headlines, such as "Race Crisis Flares Anew in Atlanta" and "Violence follows U.N. group's visit." In Windsor, Calgary, and Ottawa, news writers placed SNCC's activism within a global context, chronicling the "racial demonstrations in downtown Atlanta [which] resulted in the arrest of scores of persons Sunday in the wake of an inspection tour by a United Nations anti-discrimination group."116 In Toronto, the Globe and Mail reprinted the iconic photograph of Taylor Washington's brutal arrest: the same portrait of police brutality that Soviets saw on the pages of Pravda. However, the Toronto photojournalists went further than Soviets in showing the world the inhumanity of Jim Crow. The

111. "70 Arrested in Restaurant Incident," The West African Pilot, January 28, 1964, 8; "100 Nabbed in Civil Rights March," The West African Pilot, January 29, 1964, 2; and "86 People Held in U.S.," The Uganda Argus, January 29, 1964, 1.

112. "Café Clash: 50 Held," The Straits Times, January 28, 1964, 3.

113. "Overseas News in Brief-Arrested," The Sydney Morning Herald, January 29, 1964, 3; "Negro Comic Held Again," The Age, January 29, 1964, 20.

114. See, for example, "50 Arrested in Colour Bar Incident," The Glasgow Herald, January 27, 1964, 1; "The Racial Problem in the United States, New Incidents in Atlanta," Journal de Genève, January 28, 1964, 3; and "Blacks Arrested in the Southern USA," Gazette de Lausanne, January 28, 1964, 8.

115. "Racial Clashes in Atlanta," The Irish Times, January 27, 1964, 9.

116. "Racial Crisis Flares Anew in Atlanta," The Windsor Star, January 27, 1964, 12; "Negro, Klansmen Picket," The Calgary Herald, January 27, 1964, 1; "Violence Follows U.N. Group's Visit," The Ottawa Citizen, January 27, 1964, 4. 
Canadian paper coupled the photo of Washington's arrest with another snapshot of Southern justice: two white, powerfully built, and anonymous hands of an Atlanta police officer around the collar of a young and clearly overwhelmed SNCC marcher. The police's vicious treatment of the students was not only state sanctioned, but also appeared to receive a hearty public endorsement. The young marchers, the Toronto outlet reported, were being "hauled into paddy wagons to the applause of white spectators." 117 And in Havana, Fidelistas used the Atlanta demonstrations as an opportunity to renew that government's criticisms of United States race relations. Prensa Latina dubbed SNCC's march for human rights "[a] new phase of racial strife in America." The Cuban news agency also published two front-page photographs of contrasting images of United States democracy. One picture showed the "members of the bloody, racist U.S. organization known $\mathrm{Ku}$ Klux Klan parading in front of a restaurant in Atlanta," and the other displayed "a group of black citizens conduct [ing] a demonstration, a few steps from a restaurant, claiming their right to visit and be served in any public business." 118

When the Sub-Commission returned to New York City to finish the draft Convention, it remained steadfast to its position and Article 4 was ultimately forwarded to the Commission on Human Rights for review over the sustained protestations of the Convention's primary drafter. The presence of organizations, such as the Klan, troubled the authors of Article 4, and Abram had been unable to allay those concerns, even though he later claimed that the trip was a success. The Sub-Commission's visit had not caused the legislative shift that Abram and the State Department had hoped for. In a 1965 report to President Lyndon Johnson, federal officials privately admitted that Abram had tried, and failed, to use race relations in Atlanta to reverse the Sub-Commission's position on Article 4. "This Article was by far the most difficult and controversial aspect of the Convention, and was of primary interest to the United States inasmuch as it concerned the question of freedom of speech and association," the internal memorandum conceded. "When the Subcommission on the Protection of Minorities and Prevention of Discrimination was formulating its views on the Draft Convention, the United States Expert, Mr. Morris B. Abram, gave the members of the Subcommission an example of American democracy in action." Abram had "personally escorted members

117. "Atlanta Police Arrest 100 Anti-Segregation Demonstrators," The Globe and Mail, January 28, 1964, 31. See also "Negro Invites Ku Klux Klan Demonstrators to Sing Along," The Globe and Mail, January 27, 1964, 1; and "Racial Clashes Erupt at Café, 86 Arrested," The Globe and Mail, January 27, 1964, 8.

118. "A New Phase of Racial Strife in America," Prensa Latina, January 27, 1964, 1. 
of the Subcommission and as many observers who wished to go, to Atlanta, Georgia to observe at first hand developments and progress in race relations in a southern community. The members of the Subcommission had the opportunity of seeing demonstrations by both civil rights groups and segregationists, e.g., The Student Non-Violent Coordinating Committee (SNCC) and the Ku Klux Klan." However, despite this example of American "democracy in action," the Sub-Commission decided to retain the ban on hate speech and organizations, the memorandum acknowledged, leaving the United States delegation "particularly concerned to protect the principles of freedom of speech and association as stated in the Universal Declaration."119

Remembering Abram's diplomatic mission to Atlanta shines new light on ICERD's legislative history and provides an alternative approach to writing that story. Article 4 was easily the most controversial provision of the draft Convention. However, scholars can better appreciate how fractious the Article 4 debates were by considering the global significance of the Sub-Commission's Southern voyage. Abram was so invested in changing the Sub-Commission's position on the article that he circumvented the Sub-Commission's well-established protocol and dreamed up a once-in-a-lifetime trip for his foreign colleagues. Other federal officials were so concerned with the image of American democracy abroad, and the article's implications for the First Amendment, that the State Department allowed Abram to invite a U.N. delegation, including three officials from communist countries, to the city that represented the promise of the new South. In ratifying Article 4, the Sub-Commission had, in other words, relied on the heated discussions inside of the U.N.'s drafting rooms as well as the deliberations that occurred outside of those drafting rooms. Historians of ICERD should, therefore, employ a diverse group of primary and secondary documents, drawn from U.N. and non-U.N. sources, to reconstruct the treaty's rich drafting history. Put slightly differently, because Abram attempted to use an extralegislative space to create a political environment favorable to amending the controversial article, using archives that offer glimpses into the Sub-Commission's formal and informal deliberations can help to provide a more comprehensive account of ICERD's drafting history.

Finally, the Sub-Commission's tumultuous weekend offers a new prism for understanding the international dimensions of the Southern freedom struggle. As evidenced by the chaos in the city during Sub-Commission's visit, Atlantans were not simply pawns in the global Cold War. SNCC, in particular, used the Sub-Commission's visit as a

119. "Letter from John Means to Morris Abram," see above, note 58. 
platform for the organization to advance its own vision for domestic and international race relations. They offered a powerful counternarrative to the stories told by local and national leaders through the creative usage of sandwich board signs, flyers, letters, freedom songs, and face-to-face meetings with the international delegation. It is equally important to recognize when the Sub-Commission protests occurred. The idealistic student activists petitioned the U.N. organ in late January 1964; more than 2 months before Malcolm X boldly challenged those in the movement to "expand the civil rights struggle to the level of human rights" and "take the case of the black man in this country before the nations in the U.N." 120 However, it is Malcolm's brilliant, human rights oratory in "Ballot or the Bullet," and not SNCC's earlier appeal to the Sub-Commission, that has been enshrined in popular and scholarly memory. Perhaps implicit in this unspoken narrative is a line of reasoning that suggests that Malcolm embraced internationalism before his Southern counterparts, because he was a "radical" Northerner engaging a "more sophisticated" Northern audience. Nonetheless, this forgotten moment in SNCC's history challenges the dominant assumptions about the Southern wing of the movement. More specifically, by recovering the January 1964 U.N. protests, scholars might reperiodize their analyses of black internationalism in the movement, rethink their regional biases, and produce more deeply historicized works on these activists' appreciation for an emerging, international legal order.

\section{Democratic Legitimacy in International Human Rights Lawmaking}

However, scholars must be mindful of the limits of SNCC's human rights endeavors. The irony of ICERD's legislative history is that although SNCC activists in Atlanta were participating in the Convention deliberations, the Sub-Commission was actively excluding SNCC and many other victims of racial segregation from its formal drafting processes. The January 1964 trip to Atlanta should have demonstrated to the Sub-Commission the vital importance of expanding the formal drafting process to include more critical, non-state actors of color, if the Sub-Commission were truly interested in understanding how law might be used in diverse areas of the world to

120. Malcolm X, "The Ballot or the Bullet," in Malcolm X Speaks, ed. George Breitman, (New York: Grove Press, 1994), 23. SNCC's Atlanta protests in the winter of 1964 were not the organization's first petitions to the U.N. Following the Sixteenth Street Baptist Church bombing, for example, SNCC wired U Thant, secretary-director of the U.N. GA, and charged the United States with violating Articles 55 and 56 of the U.N. Charter. 
end the varied manifestations of racial discrimination. Discussion with the victims of Jim Crow should have, therefore, been an integral part of the Sub-Commission's formal agenda rather than the result of global diplomacy from the streets of Atlanta. ${ }^{121}$ Yet as the Atlanta tour powerfully demonstrated, Sub-Commission experts, such as Abram, were often wary of inviting increased participation from disenfranchised segments of civil society in the legislative process. Thus far, this article has explored a hidden transcript in the ICERD's legislative history and explained how SNCC, through its unconventional approach to international diplomacy, ultimately became entangled in the Articles 4 debates, in spite of a legislative design centered on the interests of powerful state actors and elite, nongovernmental organizations (NGOs). Accordingly, this section unmasks the normative dimensions of the Sub-Commission's ICERD debates. Here, I explore many of the foreign policy considerations that drove ICERD's drafting, and highlight the democratic deficits in the Sub-Commission's legislative process.

In Abram's autobiography, The Day is Short, he noted that early in his tenure on the Sub-Commission, "I was being constantly taunted by the Russians about the glaring inequities in my own country, particularly before the passage of the Civil Rights Act of 1964, which ended segregation in places of public accommodation in some of the southern states." He continued, "My answer was to invite twelve delegates of the U.N. Commission, including two Russians, to be my guests on a visit to Atlanta, Georgia."122 In January 1964, Abram faced the Scylla and Charybdis of American Cold War diplomacy. He had "tactfully withdrawn" the Sub-Commission's invitation visit to Atlanta in January 1963 because of the infamous Peyton Road incident. To cancel or postpone the trip again would not only be in poor taste but might also signal to the Sub-Commission that he was embarrassed by Atlanta's race relations. On the other hand, Abram was clearly aware that SNCC was currently leading a renewed round of racial protests in the "city too busy to hate," and voyaging into the city's racial maelstrom could easily shame Atlanta and the United States in front of the world. Abram chose the latter. "When we arrived Atlanta was pure tumult," he admitted. "[E]very pocket of the city was seething."123

121. "Letter from Morris Abram to Richard Gardner," see above, note 63.

122. The two Russians were Mr. Ivanov, U.N. Sub-Commission expert, and Mr. Ostrovsky, a Russian foreign service officer who assisted Ivanov with his English translations. "Letter from Boris Ivanov to Morris Abram," December 10, 1963, Abram Papers, Box 94, Folder 9.

123. Abram, The Day is Short, 153. 
Abram, nevertheless, had devised a plan to mitigate foreign criticisms of Jim Crow and advance American interests during the Sub-Commission's ICERD debates. He planned to recognize the existence of segregated public accommodations in the city, but would also have the Sub-Commission dine and lodge in desegregated settings. He conceded the existence of segregated urban slums but then bussed the Sub-Commission through Atlanta's affluent black suburbs, even stopping off "for tea and morning coffee at one of the gracious, sprawling homes that made up the neighborhood." He acknowledged that the SNCC protests were fueled by the students' frustrations with race relations in the United States, but simultaneously reframed the student demonstrations as "democracy in action," arranged meetings between the Sub-Commission and white Atlantans, such as "Mayor Allen ....an important capitalist who has been working like hell to achieve racial justice," and surrounded the Sub-Commission with black brokers who condemned the tactics of SNCC. ${ }^{124}$ Abram, a devout Cold Warrior, opted to host the Atlanta trip despite the demonstrations, because he believed "that in any fair debate our society, for all of its flaws, could stand inspection, but Soviet society could not." $125 \mathrm{He}$ remained steadfast that the city's openness to criticism and reform were quintessentially American, but in a 1993 interview, he confessed that he had hoped that the Atlanta visit would limit Soviet influence on the Sub-Commission by "educat[ing] foreigners on the United States and what we regarded as a model city."126

Abram's Cold War strategy epitomized the shortcomings in international human rights lawmaking. As the goals of the Atlanta tour revealed, the ICERD debates offered a new battlefield for launching Cold War attacks and, more generally, advancing a nation's foreign policy objectives. Human rights discourse was integral in this endeavor, because the language of human rights-with its purported "natural" origins, apolitical process, and egalitarian ends-masked and legitimized the ideological conflict, which permeated the ICERD debates. Abram later disclosed in his memoir that "in 1964, if Ivanov and I had engaged in an informed and honest discussion ...I would have been obliged to confess that generations of prejudice and neglect left the United States with a group of blacks who were not making it." 127 During the ICERD debates, human rights often took a back seat to the Cold War. Abram, therefore, attempted to exclude SNCC from the Sub-Commission's agenda in Atlanta, because he understood that the

124. Ibid.

125. Ibid., 152-53.

126. Abram Oral History, 6.

127. Abram, The Day is Short, 152-53. 
student organizers might undermine the foreign policy goals he aspired to achieve in his human rights advocacy. The results were paradoxical. Abram, the primary drafter of a race treaty designed to end de jure and de facto discrimination, sought to silence activists, who organized daily in the South's segregated slums and represented many of interests of those most vulnerable to Jim Crow's hardships.

Had the Sub-Commission formally acknowledged the role of the Atlanta freedom struggle in the Article 4 debates, they might have also exposed a host of other conceptual faults in the U.N.'s formal legislative process. At the heart of these democratic deficits was the U.N.'s conception of racial expertise. The U.N. officially recognized the Sub-Commission's members as racial "experts." Such a designation explicitly privileged the knowledge and perspectives of state actors, not the views of organizations such as SNCC, in the human rights debate. The U.N.'s selection of the term "expert" became even more troubling when considering the geographical composition and ideological direction of the Sub-Commission. Of the fourteen racial "experts" on the Sub-Commission, seven were from Europe alone. The Sub-Commission's legislative agenda was dominated by state actors from the global North from the start of the January 1964 session. Three draft Conventions - those of Morris Abram (United States), Peter Calvocoressi (United Kingdom), and Boris Ivanov (Russia) and Wojceich Ketrzynski (Poland) jointly-served as the bases for the Sub-Commission's work, and accordingly structured the terms of the ICERD debates around the foreign policy goals of the world's superpowers. ${ }^{128}$ The 1964 Sub-Commission's legislative structure placed inordinate amounts of power in the hands of the very nations that had perpetuated many of history's most egregious human rights violations. Those same nations were contemporaneously engaged in an imperialistic struggle to control the destiny of the Third World. The Sub-Commission's legislative process reinforced long-standing hierarchies in global race relations, as it dismissed the black South and much of the so-called "Third World" as sites for the epistemological production of human rights.

The U.N.'s faith in many of the state actors invited to participate in the formal ICERD deliberations was misplaced. Perhaps nothing demonstrated this more than a letter from Marie-Helene Lefaucheux, French diplomat and Chair of the U.N. Commission on Women, to Abram in the days following the Atlanta protests. Although Lefaucheux had "tried to increase [her] understanding of the American situation," she confessed to Abram, "Truthfully said, it is scarcely possible for the French people to understand

128. Lerner, The U.N. Convention on the Elimination of All Forms of Racial Discrimination, 5. 
the core of these [racial] difficulties."129 Lefaucheux's own words divulged her lack of qualifications to help draft a treaty, which aimed to eliminate all forms of racial discrimination. She closed her letter to Abram, "In the specific area of my commission regarding the situation of women, I can conclude that no discrimination 'based on sex'-to adopt the term of the Universal Declaration-exists with respect to negro women."130

Lefaucheux's ignorance, particularly given her position at the U.N., was egregious, and the Sub-Commission's exclusion of critical women of color from the legislative process had serious, long-term consequences. The allmale Sub-Commission adopted a single-axis approach to addressing worldwide manifestations of racial discrimination. In turn, the gendering of the legislative process and Convention itself impeded women's abilities to raise cognizable human rights claims under ICERD. The Convention endorsed a sexist logic, which established that women were "worthy" of legal protection only in those instances in which their experiences corresponded with men's experiences. The Convention, at the same time, legitimized national laws and customs that punished women of color for failing to conform to the norms expected of men. Intersectional discrimination and violence, particularly in the private sphere, went uninvestigated and unpunished by human rights "experts" for decades after the ratification of ICERD. ${ }^{131}$ Because the U.N. has historically treated race and gender discrimination as separate issues and developed separate mechanisms for addressing each form of subordination, U.N. officials admit that even today, many women of color are left "unsure of where to turn for redress."132

129. "Letter from Marie-Helene Lefaucheux to Morris Abram," January 31, 1964, Abram Papers, Box 94, Folder 9.

130. Ibid.

131. See, for example, U.N. Committee on the Elimination of Racial Discrimination, General Recommendation No. XXV: Gender-Related Dimensions of Racial Discrimination (March 20, 2000), reprinted in Compilation of General Comments and General Recommendations Adopted by Human Rights Treaty Bodies, U.N. Doc. HRI/ GEN/1/Rev.7 (May 12, 2004); Johanna E. Bond, "International Intersectionality: A Theoretical and Pragmatic Exploration of Women's International Human Rights Violations," Emory Law Journal 52 (2003): 71; Catherine Powell, and Jennifer H. Lee, "Recognizing the Interdependence of Rights in the Antidiscrimination Context Through the World Conference Against Racism," Columbia Human Rights Law Review 34 (2002): 235; and Lisa A. Crooms, "Indivisible Rights and Intersectional Identities or, "What Do Women's Human Rights Have to Do with the Race Convention?" Howard Law Journal 40 (1997): 619.

132. United Nations Office of the High Commissioner for Human Rights, Gender Dimensions of Racial Discrimination (Geneva: United Nations, 2001). This confusion about where women of color should seek legal redress has continued, in part, because in 1981, the U.N. began enforcement of the Convention on the Elimination of all Forms of Discrimination against Women-another single-axis treaty. 
By failing to confront the multiple dimensions of subordination, the Convention's sexist framework has undercut the U.N.'s goal to eliminate all forms of racial discrimination.

The Sub-Commission's exclusionary practices highlight a larger, more systemic flaw in the U.N legislative processes of the early 1960s. Article 71 of the U.N. Charter and GA resolution $288 \mathrm{~B}(\mathrm{X})$ of 1950 outlined the legal relationship between U.N. organs and NGOs, and these provisions established the principle that only NGOs with "consultative status" may formally provide commentary and technical analysis to U.N. bodies, such as the Sub-Commission. ${ }^{133}$ The results of these legal provisions were predictable. During the early 1960 s, in particular, consultative status encumbered participation in the human rights debates by NGOs from the global South, and accordingly undermined the democratic legitimacy of the international legislative process. These NGOs frequently lacked the resources for sustained foreign lobbying and travel, and were often unable to develop meaningful institutional connections within the U.N. Law transformed into an instrument of racial subordination, privileging the participation of elite NGOs from the global North, and failing to facilitate the participation of those individuals whom the Convention was designed to benefit. Consequently, like the ideological tenor and geopolitical composition of the Sub-Commission, the Sub-Commission's reliance on NGOs with consultative status in the formal drafting process reinforced the "savior-victim" binary that persists in international human rights lawmaking. ${ }^{134}$

The exclusion of Southern NGOs from the January 1964 session is particularly problematic when considering the Sub-Commission's emphases during the ICERD debates. For example, although the Sub-Commission was preoccupied with ending apartheid in South Africa, the SubCommission failed to invite any South African freedom fighters to inform and enrich its discussions of the proposed Convention. ${ }^{135}$ Of the 37

133. The GA reviewed these rules, and through GA resolution 1296 of 1968 , the GA established additional criteria for NGO participation. See also Arrangements for Consultation with Non-Governmental Organizations, U.N. ESCOR Res.1296 (XIIV), 1520th Plenary Meeting, http://www.globalpolicy.org/ngos/ngo-un/info/res-1296.htm (May $23,1968)$.

134. See James Peacock, Harry Watson, and Carrie Matthews, The American South in a Global World (Chapel Hill: University of North Carolina Press, 2005); and Makua Mutua, "Savages, Victims, and Saviors: The Metaphor of Human Rights," Harvard International Law Journal 42 (2001): 201. It is admirable that Abram expanded the drafting process to include an informal dimension, where groups without consultative status could participate in shaping the Convention. Nonetheless, it is essential to interrogate Abram's motives for expanding participation in the drafting process.

135. See ICERD, art. 3. Article 3 declares, "States Parties particularly condemn racial segregation and apartheid and undertake to prevent, prohibit and eradicate all practices of this 
NGOs with consultative status who formally participated in the Sub-Commission's January 1964 session, only one NGO was from the Third World. ${ }^{136}$ SNCC became part of the Sub-Commission's informal agenda in late January 1964, simply because of the organization's unremitting, extraparliamentary efforts. Despite the Sub-Commission's liberatory rhetoric and ostensible commitment to racial justice, its formal legislative process largely muted the voices of racially oppressed people-ultimately positioning them as passive objects to be spoken for by more "enlightened" actors from the global North.

\section{Conclusion}

The Sub-Commission's trip to Atlanta in late January 1964 transformed the city into a local battlefield in the global Cold War. Abram enlisted allies from Atlanta's human rights community to aid his pursuit of American foreign policy objectives, and Abram, like many of his peers on the Sub-Commission, relied on the ostensibly, apolitical language of human rights to hurl thinly veiled attacks on his ideological rivals. However, as the messy drafting history of ICERD vividly illustrates, the foot soldiers of the Atlanta student movement attempted to disrupt Abram's mission. They complicated Abram's attempt to showcase the racial diplomacy among local blue bloods as representative of race relations in the city and nation, leveraged the U.N. visit for their own purposes, and even indirectly provided Sub-Commission members, such as the Soviet Ivanov, with a new opportunity to launch a counteroffensive regarding the image of American democracy.

nature in territories under their jurisdiction." Spirited and numerous debates within the U.N. left no doubt that the Sub-Commission's references to apartheid primarily concerned the repressive governmental practices that institutionalized Afrikaner supremacy in South Africa. Since 1946, the U.N. had passed a wide array of resolutions regarding racial conflict in South Africa resulting from the policies of government-sponsored racism. Most notably, the GA issued Resolution 1761 (XVII) in November 1962, which proclaimed that apartheid practices in South Africa violated the U.N. Charter, and requested that member states adopt a variety of diplomatic and trade sanctions to encourage the end of the apartheid regime in South Africa. See U.N. Res. 44 (I) (December 8, 1946); U.N. Res. 395 (V) (December 2, 1950); U.N. Res. 615 (VII) (December 5, 1952); U.N. Res. 1179 (XII) (November 26, 1957); U.N. Res. 1302 (XIII) (December 10, 1958); U.N. Res. 1460 (XIV) (December 10, 1959), U.N. Res. 1597 (XV) (April 13, 1961); U.N. Res 1662 (XVI) (November 28 1961); and U.N. Res. 1761 (XVII) (November 6, 1962).

136. Sub-Commission on Prevention of Discrimination and Protection of Minorities, Summary Record of the Four Hundred And Twenty-Fifth Meeting, E/CN.4/Sub.2/L.345. 
Studying Cold War battlefields, such as Atlanta, as sites important to the transformation of international human rights law, repositions the United States South in transnational legal studies and invites fuller, more textured explorations of Southern black activism. Given the centrality of the United States in the Sub-Commission's deliberations during the early and mid-1960s, Abram's role as the primary drafter of the Convention, and black activists' ability to attract international attention during the Cold War, it is imperative for scholars to continue reconsidering the role of the Jim Crow South in the development of ICERD. Such a nuanced approach to the history of the Convention is not only critical to bridging a gap in ICERD's historiography, but also vital to revealing a small, but crucial, point about the scope of the freedom movement in the heart of the United States South: that, as the SNCC affiliate in Atlanta challenged racial discrimination in their municipality, their actions helped to shape the debates over the future of their region, nation, and world. 
$\infty$ 